Review

\title{
New Opportunities for Oil and Gas Exploration in Poland-A Review
}

\author{
Krystian Wójcik ${ }^{1, *} \mathbb{D}^{\mathbb{D}}$, Jarosław Zacharski ${ }^{1}$, Marcin Łojek ${ }^{1}$, Sara Wróblewska ${ }^{1}$, Hubert Kiersnowski ${ }^{1}$, \\ Krzysztof Waśkiewicz ${ }^{1}$, Adam Wójcicki ${ }^{1}$, Rafał Laskowicz ${ }^{1}$, Katarzyna Sobień ${ }^{1}$, Tadeusz Peryt ${ }^{1}{ }^{1}$, \\ Agnieszka Chylińska-Macios ${ }^{2}$ and Jagoda Sienkiewicz ${ }^{2}$
}

1 Polish Geological Institute-National Research Institute, 4 Rakowiecka St., 00-975 Warsaw, Poland; jzach@pgi.gov.pl (J.Z.); mloj@pgi.gov.pl (M.Ł.); swro@pgi.gov.pl (S.W.); hkie@pgi.gov.pl (H.K.); kwas@pgi.gov.pl (K.W.); awojci@pgi.gov.pl (A.W.); rlas@pgi.gov.pl (R.L.); ksob@pgi.gov.pl (K.S.); tper@pgi.gov.pl (T.P.)

2 Department of Geology and Licensing, Ministry of Climate and Environment, 52/54 Wawelska St., 00-922 Warsaw, Poland; agnieszka.chylinska-macios@klimat.gov.pl (A.C.-M.); jagoda.sienkiewicz@mos.gov.pl (J.S.)

* Correspondence: kwoj@pgi.gov.pl

check for updates

Citation: Wójcik, K.; Zacharski, J.; Łojek, M.; Wróblewska, S.; Kiersnowski, H.; Waśkiewicz, K.; Wójcicki, A.; Laskowicz, R.; Sobień, K.; Peryt, T.; et al. New Opportunities for Oil and Gas Exploration in Poland-A Review. Energies 2022, 15, 1739. https://doi.org/10.3390/ en15051739

Academic Editor: Dameng Liu

Received: 24 January 2022

Accepted: 18 February 2022

Published: 25 February 2022

Publisher's Note: MDPI stays neutral with regard to jurisdictional claims in published maps and institutional affiliations.

Copyright: (C) 2022 by the authors. Licensee MDPI, Basel, Switzerland. This article is an open access article distributed under the terms and conditions of the Creative Commons Attribution (CC BY) license (https:// creativecommons.org/licenses/by/ $4.0 /)$.

\begin{abstract}
Reserves totaling 142 BCM (5 TCF) of natural gas trapped in 306 fields and 22 MTOE ( 157 MMBOE) of crude oil in 87 fields have been discovered. The prospection, exploration, and production of hydrocarbons are licensed: an entity interested in these kinds of activities needs to have concession, which is granted by the Polish Ministry of Climate and Environment for 10 to 30 years according to one of two independent ways-international tender or open door procedure. In this review, the most prospective areas for oil and gas exploration in Poland, selected by the Polish Geological Survey, and announced as dedicated for the next 6th tender round, planned in the second half of 2022, are described. These are: Block 413-414, Block 208, Cybinka-Torzym, Zielona Góra West, and Koło areas. The main exploration target of these tender areas is related to conventional and unconventional accumulations of gas and oil in the Carpathian basement, Carpathian Foredeep, and Outer Carpathians (Block 413-414), as well as in the Carboniferous, Permian Rotliegend, Zechstein Main Dolomite (Block 208, Cybinka-Torzym, Zielona Góra West), and in the Mesozoic of the Polish Lowlands (Koło). The second way of granting concession in Poland is the so-called open door procedure, in which an entity may apply for a concession for any other area selected on its own.
\end{abstract}

Keywords: oil and gas exploration opportunities; prospective areas; concession policy

\section{Introduction}

Oil and gas exploration and production in Poland can be traced back to the nineteenth century. At that time, they were limited to the production of oil from the Outer Carpathian flysch belt in southern Poland. Since that time, plenty of oil and gas fields have been discovered in the Carpathian Foreland and Polish Lowland areas. Moreover, new perspectives appeared in the unconventional systems related to the shale-gas and tight-gas accumulations in various horizons. In this review, the current state of view concerning the most prospective geological horizons and their lateral extent for oil and gas exploration in Poland is presented.

According to the latest balance of mineral resources deposits in Poland, a report, which is published annually by the Polish Geological Survey [1,2], reserves totaling 142 BCM (5 TCF) of natural gas trapped in 306 fields, and 22 MTOE ( 157 MMBOE) of crude oil in 87 fields have been discovered in Poland (Figure 1). In 2020, natural gas production exceeded 4.9 BCM (174 BCF), which constitutes approximately $22 \%$ of national demand ranging $22 \mathrm{BCM}$ (775 $\mathrm{BCF})$. Crude oil production reached almost $1 \mathrm{MTOE}(\sim 6.5 \mathrm{MM}-$ BOE), covering $\sim 3.7 \%$ of $\sim 27$ MTOE (192.9 MMBOE) demand. This illustrates a huge 
gap between supply and demand in Poland, which may be balanced somewhat by new discoveries expected in different geological horizons. For comparison, proven natural gas resources in 2020 in Europe, excluding Russia and Belarus, were 3.2 TCM ( 111.9 TCF) with production $\sim 218.6 \mathrm{BCM}(\sim 7.7 \mathrm{TCF})$; total World proved gas reserves were $\sim 188.1 \mathrm{TCM}$ $(\sim 6641.8 \mathrm{TCF})$ [3]. Gas resources in Poland accounted for only $4.5 \%$ of the resources of the whole of Europe. In the same way, total proved reserves of oil in Europe were $1800 \mathrm{MTOE}$ $(\sim 13,600$ MMBOE) with production $\sim 167,100$ MTOE ( 1,224,843 MMBOE); World reserves were $\sim 244,400$ MTOE [3]. Oil resources in Poland accounted for only $1.2 \%$ of the resources of Europe. Global energy consumption growth declined by $4 \%$ in 2020, in the context of the global pandemic, contrasting with an average of 2\%/year over the 2000-2018 period [3]. Consumption in 2020 in Europe, excluding Russia and Belarus, was 14\% of global energy consumption; oil and gas continue to hold the largest share of the energy mix (58\%) [3].
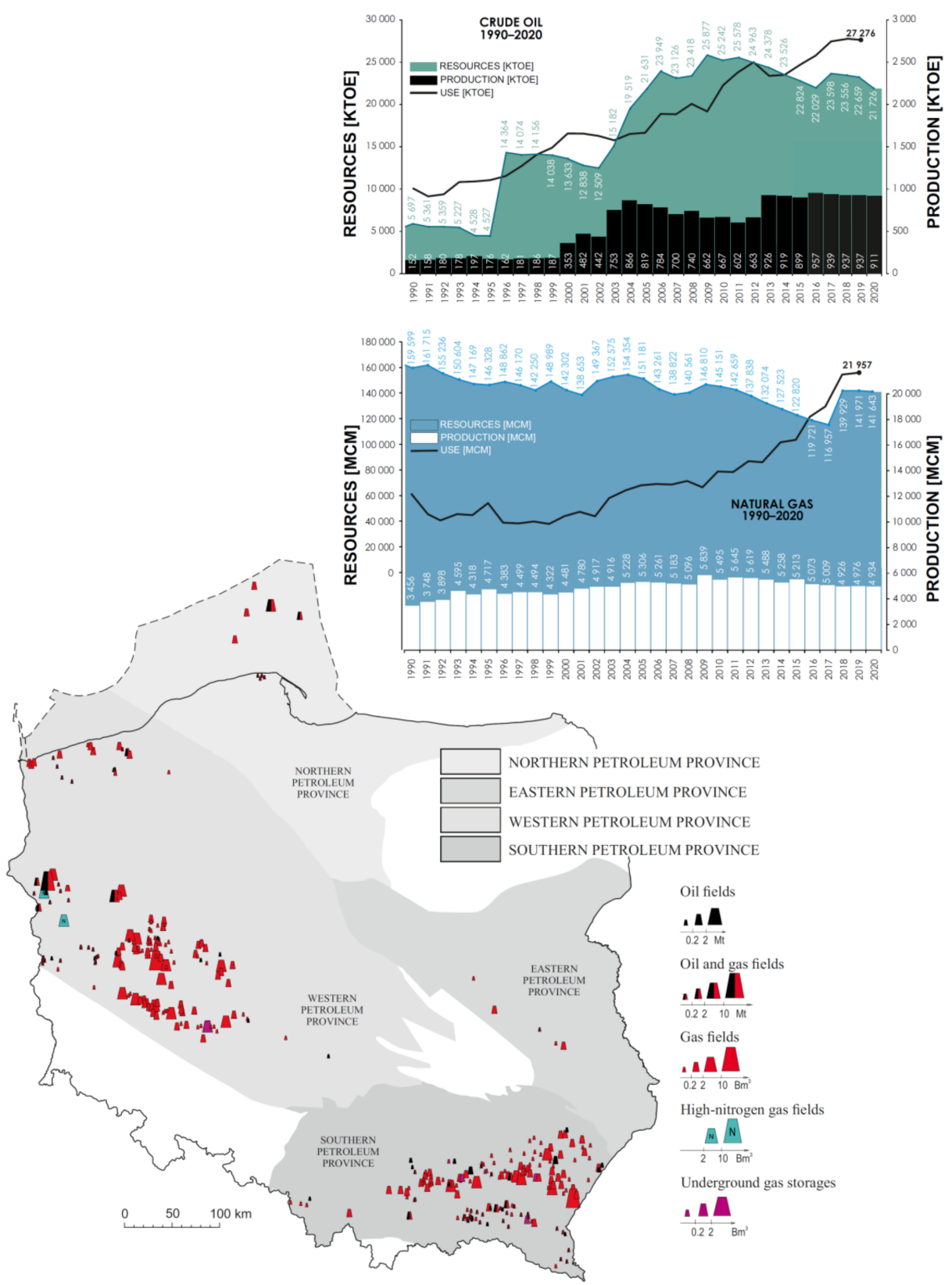

Figure 1. Crude oil and natural gas resources, production, and use in Poland 1990-2020 according to the Balances of mineral resources deposits in Poland [1,2]; location of oil and gas fields and underground gas storages in Poland in relation to petroleum provinces ([4]; compare to [5-7]). 
The majority of European hydrocarbon reserves (excluding Russia) is located in the North Sea region within the Northern Permian basin, where reservoirs ranging from Carboniferous to Tertiary are present, e.g., [8], although the Adriatic region also has a long exploration history concerning hydrocarbon potential, e.g., [9,10], France, e.g., [11,12], Spain, e.g., [13], Italy, e.g., [14,15], Vienna Basin, e.g., [16], the Carpathians and their foreland in Czech, Poland, Ukraine, and Romania, e.g., [17-23], Transylvania, e.g., [20,24], Eastern Ukraine, e.g., [25] and the Black Sea, e.g., [26]. In Poland, new small- or mediumsized gas and oil fields continue to be discovered (e.g., Brzyska Wola, Czarna Wieś, Olchowiec, Pniewy, Rogoźnica, Wielichowo W, Gnojnica gas fields with total reserves of $\sim 5.8 \mathrm{BCM} / 206 \mathrm{BCF}$, and Połęcko oil and gas field of total reserves of gas $\sim 2.3 \mathrm{MCM} / 81$ MCF and oil $12.3 \mathrm{kTOE} / 87.6 \mathrm{MBOE}$; all of them documented by the Polish Oil and Gas Company in 2019-2020 in the Carpathian Foredeep and Polish Lowland) [1,2], which suggests the existence of still-unexplored regions. The primary targets of exploration are currently conventional reservoirs. Geologists have also identified a host of unconventional resources-including shale gas, tight gas, and coal bed methane ([27]; see also, e.g., [28-43] and citations therein). Oil (petroleum) provinces in Poland, in which exploration and production work can be conducted, have been defined by various authors [5-7]. In the PGS Report [4], the authors described four petroleum provinces (divided into sub-provinces of proved accumulations and regions of unconfirmed oil and gas occurrence), which included prospective areas for oil and gas conventional and unconventional accumulations in different geological regions (Figures 1-3): Northern and Eastern Petroleum Provinces for the East European Platform areas, Western Petroleum Province for the West European (Variscan) Platform, and Southern Petroleum Province for the Carpathian units and its basement. The main exploration targets, documented fields, as well as their documented and prospective resources are summarized in Table 1.

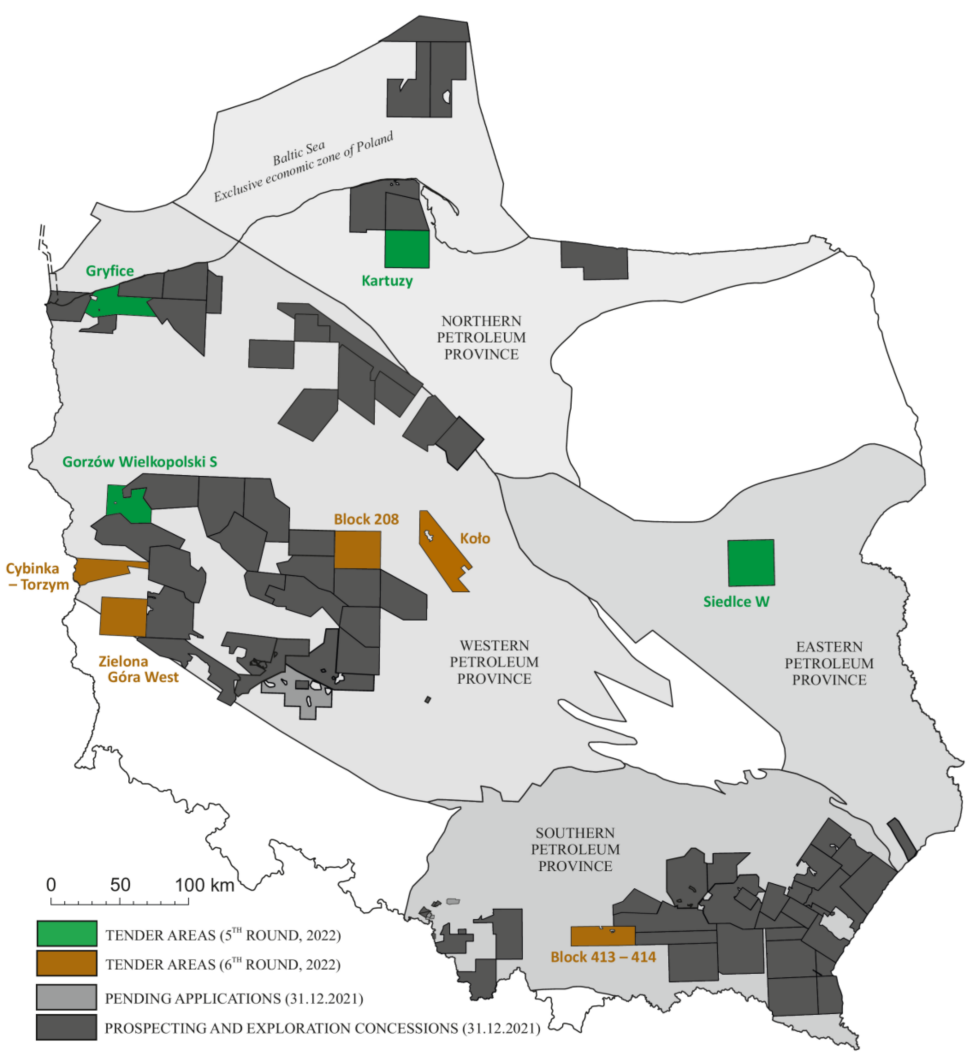

Figure 2. Cont. 


\begin{tabular}{|c|c|}
\hline ROUND V TENDER AREAS & TARGET \\
\hline GORZÓW WIELKOPOLSKIS & Permian (Main Dolomite ${ }^{c}$ ) \\
\hline GRYFICE & Permian (Main Dolomite ${ }^{c}$ and Rotliegend ${ }^{c}$ ): Carboniferous ${ }^{c}$ \\
\hline KARTUZY & Lower Paleozoic ${ }^{\text {vas }}$; Cambrian ${ }^{\text {cun }}$ \\
\hline SIEDLCE W & Lower Paleozoic $^{\text {Usm }}$; Cambrian ${ }^{C}$ \\
\hline ROUND U TENDER AREAS & TARGET \\
\hline BLOCK $413-414$ & Outer Carpathians ${ }^{c}$, Carpathian Foredeep ${ }^{c}$, Carpathian basement ${ }^{c}$ \\
\hline BLOCK 208 & $\begin{array}{l}\text { Carboniferous, Permian } \\
\left(\text { Culm }^{\mathrm{u}}, \text { Rotiegend }{ }^{\mathrm{c}}, \text { Main Dolomite }\right.\end{array}$ \\
\hline KOto & 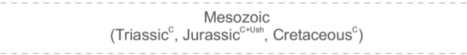 \\
\hline CYBINKA-TORZYM & $\begin{array}{c}\text { Permian } \\
\text { (Rotliegend }{ }^{c} \text { and Main Dolomite }{ }^{c} \text { ) }\end{array}$ \\
\hline ZIELONA GÓRA WEST & $\begin{array}{c}\text { Permian } \\
\text { (Rotliegend }{ }^{c} \text { and Main Dolomite }{ }^{c} \text { ) }\end{array}$ \\
\hline
\end{tabular}

Figure 2. Concessions for prospecting and exploration of hydrocarbon deposits together with concessions for prospecting and exploration of hydrocarbon deposits and production of hydrocarbons from deposit in relation to tender areas dedicated to 5th and 6th tender round and petroleum provinces of Poland.

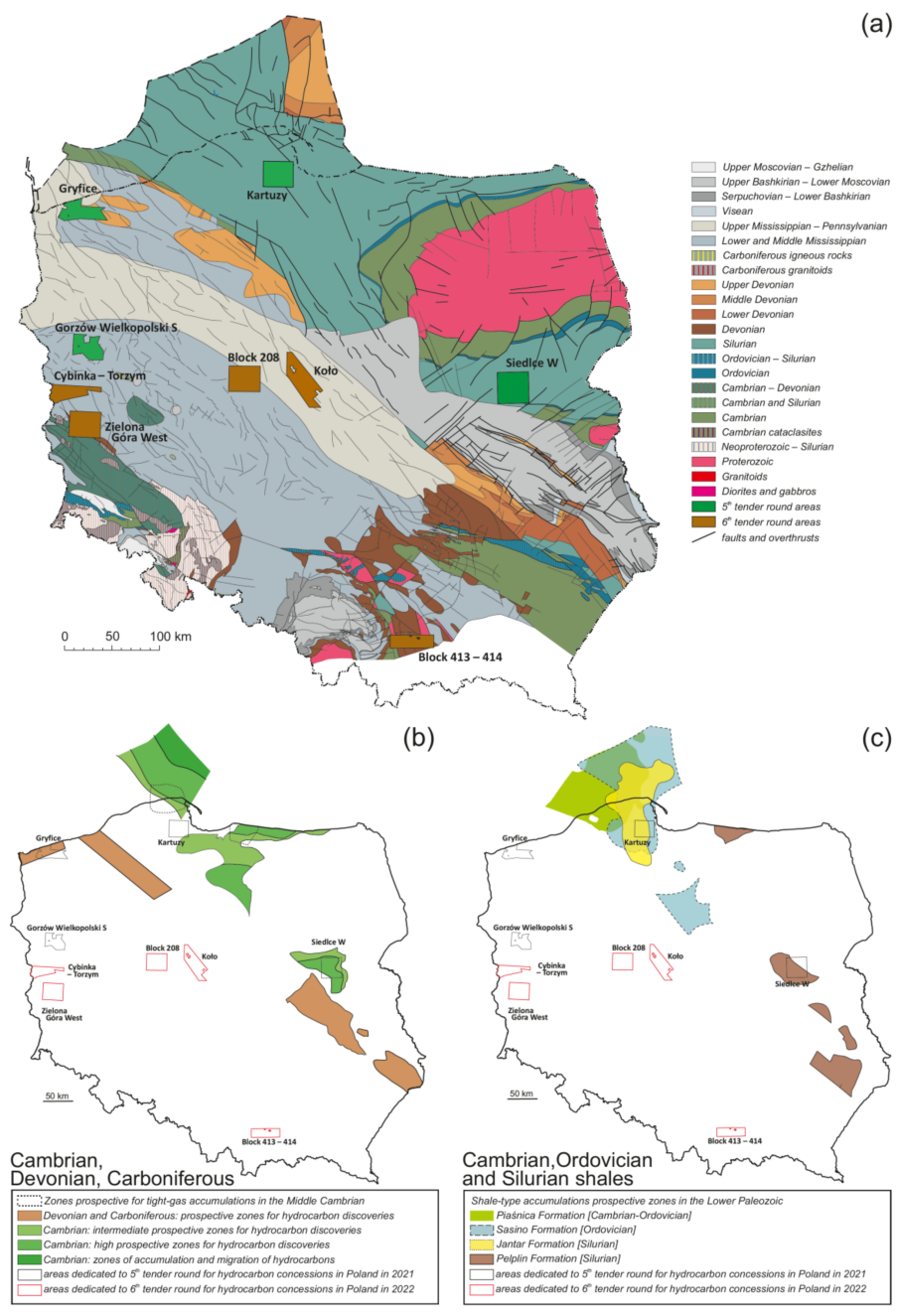

Figure 3. Location of the areas dedicated to the 5th and 6th tender rounds for hydrocarbon concessions: (a) on the Geological map of Poland without Permian and younger deposits ([44], simplified); (b) in relation to the prospective areas for conventional hydrocarbon accumulations in the Cambrian [45,46], Devonian, and Carboniferous ([47]; see also [48-50]) and prospective areas for tight-gas accumulations in the Middle Cambrian [27,37,39]; (c) in relation to the prospective areas for unconventional hydrocarbon accumulations in Lower Paleozoic shale formations [36]. 
In the Northern and Eastern Petroleum Provinces, conventional and unconventional (tight-type) accumulations in the Middle Cambrian sandstones [27,37,39,45,46,48,51-53], unconventional accumulations in the Lower Paleozoic shales [27-36], and Devonian and Carboniferous carbonate and clastic rocks [47-50] are expected (Figure 3). In total, 14 gas fields of resources of $\sim 6.4 \mathrm{BCM}(\sim 226 \mathrm{BCF})$ and annual production of $\sim 57 \mathrm{MCM}(\sim 2 \mathrm{BCF})$ of natural gas in 2020, and 8 oil fields of resources of $\sim 6.3 \mathrm{MMTOE}(\sim 45 \mathrm{MMBOE})$ and annual production in 2020 of $\sim 229 \mathrm{kTOE}(\sim 1.6 \mathrm{MMBOE})$ are documented in these provinces (Table 1; Figure 1). According to the balance of prospective resources deposits in Poland [27], unconventional (technically exploitable) resources of shale gas in the Lower Paleozoic strata are estimated at $\sim 202.0-788.3$ BCM ( 7.1-27.8 TCF), while tight gas (technically exploitable) resources of the Cambrian Sandstones equal $\sim 38.0$ BCM ( 1.3 TCF). In the Western Petroleum Province, oil and gas fields occur in the Carboniferous and three Permian horizons-Rotliegend, Zechstein Limestone, and Main Dolomite (Figure 4). Currently, 148 gas fields of resources of $\sim 104 \mathrm{BCM}(\sim 3.7 \mathrm{TCF})$ and annual production of $\sim 3.5 \mathrm{BCM}(\sim 124.3 \mathrm{BCF})$ of natural gas in 2020, and 38 oil fields of resources of $\sim 14.4 \mathrm{MTOE}$ ( 102.7 MMBOE) and annual production of $\sim 650 \mathrm{kTOE}(\sim 4.6 \mathrm{MMBOE})$ are documented in this province (Table 1; Figure 1). The unconventional tight gas (technically exploitable) resources of the Carboniferous and Permian/Rotliegend sandstones equal 1.5-2.0 TCM ( 53.0-70.6 TCF) [27]. In the Southern Petroleum Province, oil and gas fields occur in the Paleozoic-Mesozoic basement, autochthonous Miocene of the Carpathian Foredeep, and flysch belt of the Outer Carpathians. Currently, 144 gas fields of resources of $33.1 \mathrm{BCM}$ $(\sim 1.2 \mathrm{TCF})$ and annual production of $\sim 1.4 \mathrm{BCM}(\sim 48.0 \mathrm{BCF})$ of natural gas in 2020 and 41 oil fields of resources of $\sim 1.5 \mathrm{MTOE}(\sim 10.7 \mathrm{MMBOE})$ and annual production of $\sim 32.9 \mathrm{kTOE}$ ( 235.2 MBOE) are documented in this province (Table 1; Figure 1).

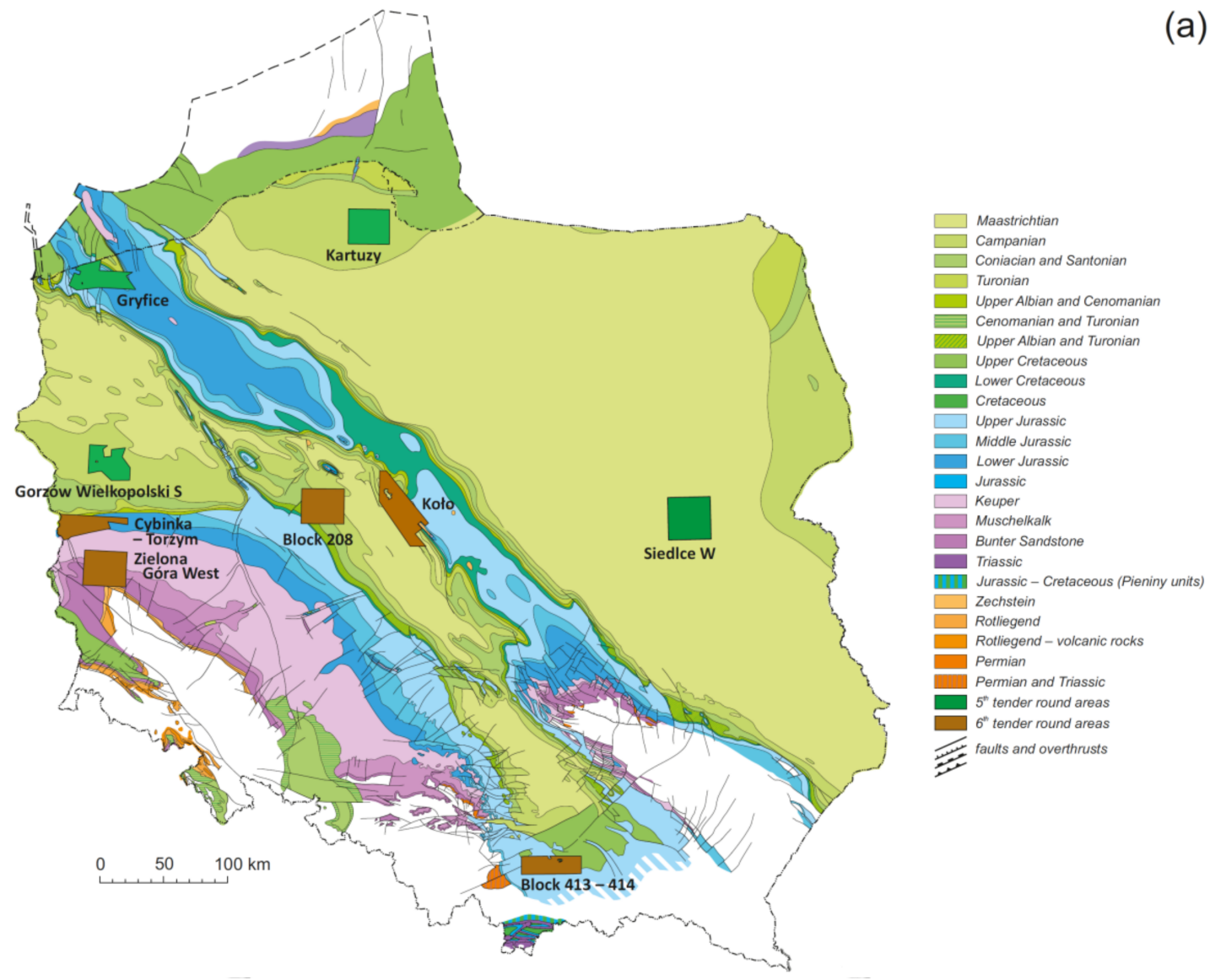

Figure 4. Cont. 

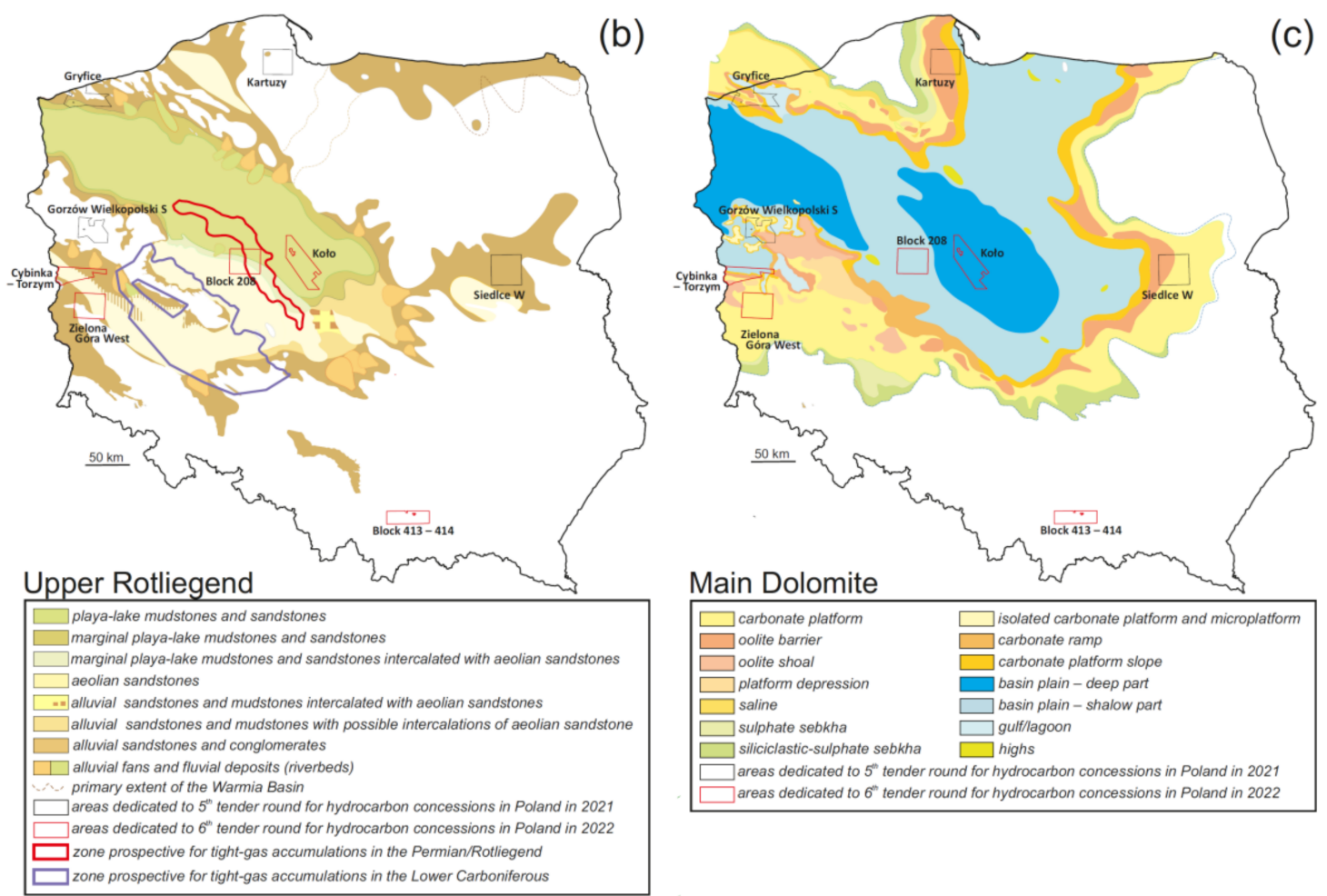

Figure 4. Location of the areas dedicated to the 5th and 6th tender rounds for hydrocarbon concessions: (a) on the Geological map of Poland without Cenozoic deposits ([54], simplified); (b) in relation to the Upper Rotliegend facies distribution [55] and prospective zones for tight-gas accumulations in the Permian/Rotliegend and Lower Carboniferous [27]; (c) in relation to the Permian/Zechstein Main Dolomite facies distribution [56].

The exploration activities can be conducted under the existing Polish licensing regime. Every entity interested in obtaining a hydrocarbon concession in Poland needs to go through the qualification procedure, being assessed in terms of state security. The application form and the requirements regarding the attachments are set out in the Regulation of the Council of Ministers [57]. According to the Polish Geological and Mining Law [58], current regulations allow two methods by which concessions can be granted. The first is the international tender procedure announced by the Polish Minister of Climate and Environment; the second is an open-door procedure, in which an entity may apply for a concession in any area that is not the subject of a tender or other concession and does not exceed an area of $1200 \mathrm{~km}^{2}$ (see also [59-63]). At the end of October 2021, Poland operated 18 concessions for prospecting and exploration of hydrocarbon deposits, 53 concessions for prospecting and exploration of hydrocarbon deposits and production of hydrocarbons from the deposit, and 195 concessions for hydrocarbon production from the deposit. Moreover, 4 areas are dedicated to the 5 th tender round for hydrocarbon concessions in Poland: Gorzów Wielkopolski S, Gryfice, Kartuzy, and Siedlce W tender areas (Figures 2-4) (see [63]). The tender round is planned to begin in the first half of 2022. 
Table 1. Principal geological horizons of crude oil and natural gas occurrences in Poland with several fields, documented resources, production, and prospective conventional and unconventional reserves (see Figures 3 and 4) $[1,2,27,48]$.

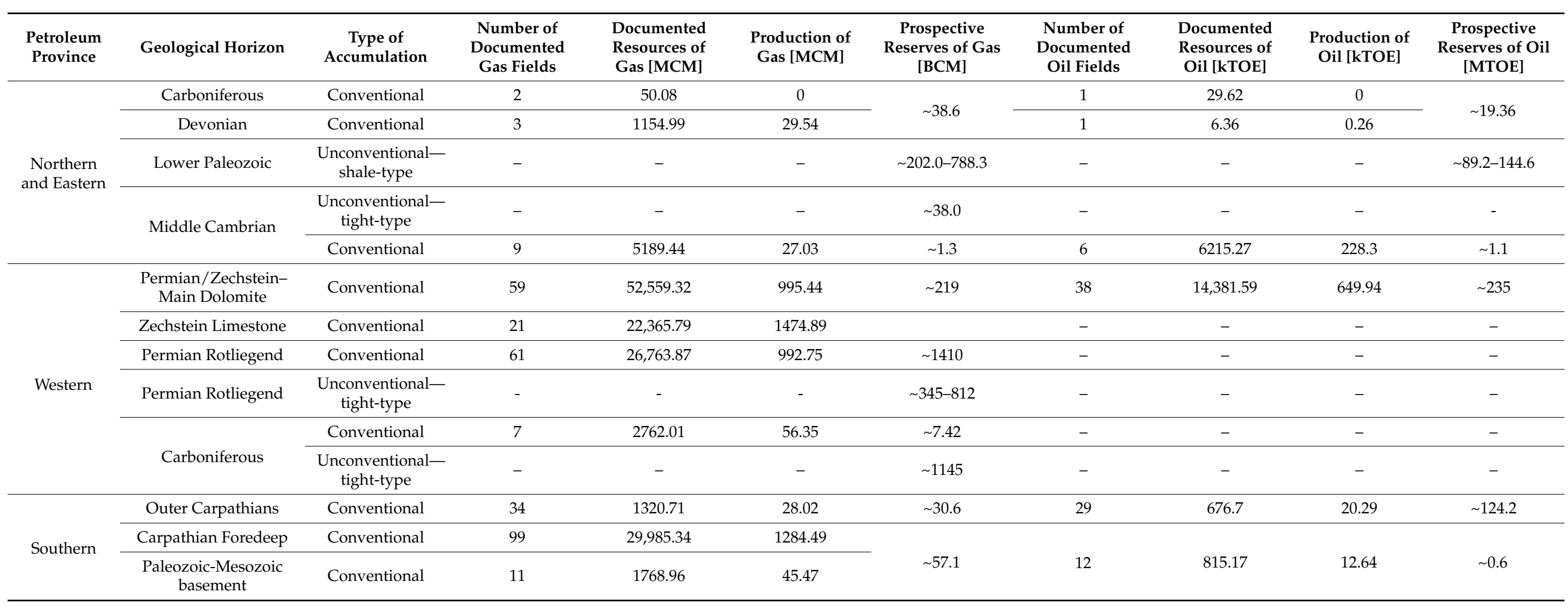




\section{Materials and Methods}

Every year, the geologists of the Polish Geological Institute-National Research Institute and the Department of Geology and Licensing of the Ministry of Climate and Environment indicate prospective areas-promising for discoveries of conventional and unconventional oil and gas deposits, based on the geological data resources stored in the National Geological Archive. From these propositions, the Polish Minister of Climate and Environment selects the areas dedicated to the international tender, which is organized to grant the concession for prospection and exploration of hydrocarbon deposits and production of hydrocarbons from the deposit.

Many prospects related to the shale-gas and shale-oil exploration during the socalled shale boom in Poland (2008-2015), as well as several research projects of the Polish Geological Survey, research institutions, and universities, dedicated to unconventional accumulations of hydrocarbons [27-43], brought new light into exploration opportunities in Poland, especially in the areas which were not previously considered as promising for new discoveries. This review refers to the results of the analysis of 127 final geological reports from the concessions, which operated during the shale boom in Poland and now are expired. Special attention was paid to why the concession expired, the scope of geological work performed, and the assessment of petroleum prospects from the entrepreneur's point of view. As a result, five new prospective areas (free from other concessions and tender) have been selected and indicated for further exploration: Cybinka-Torzym, Zielona Góra West, Block 208, Koło, and Block 413-414 (Figures 2-5). These areas are announced by the Polish Ministry of Climate and Environments as dedicated to the 6th tender round for hydrocarbon concessions planned in the second half of 2022 [64].

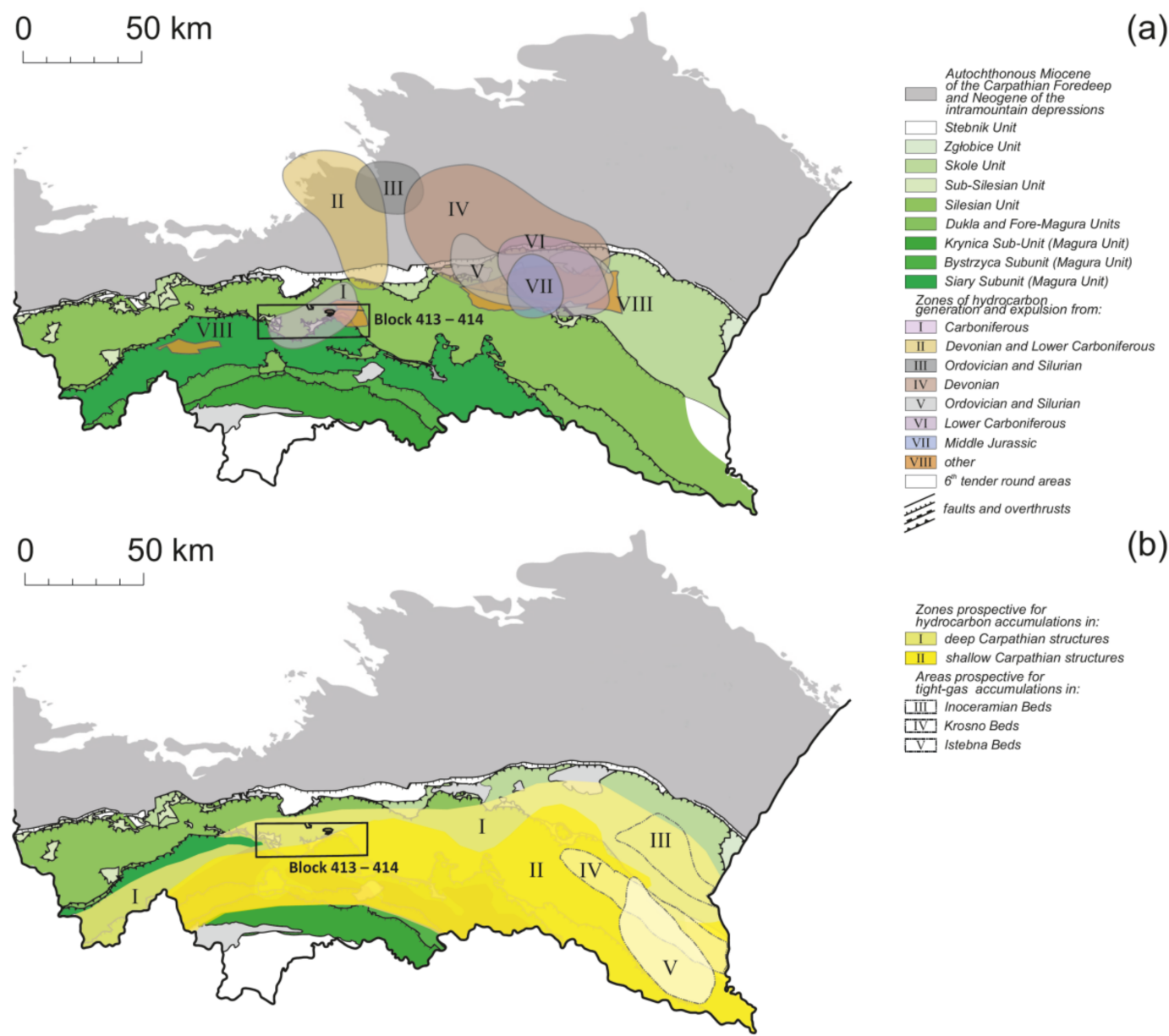

Figure 5. Cont. 


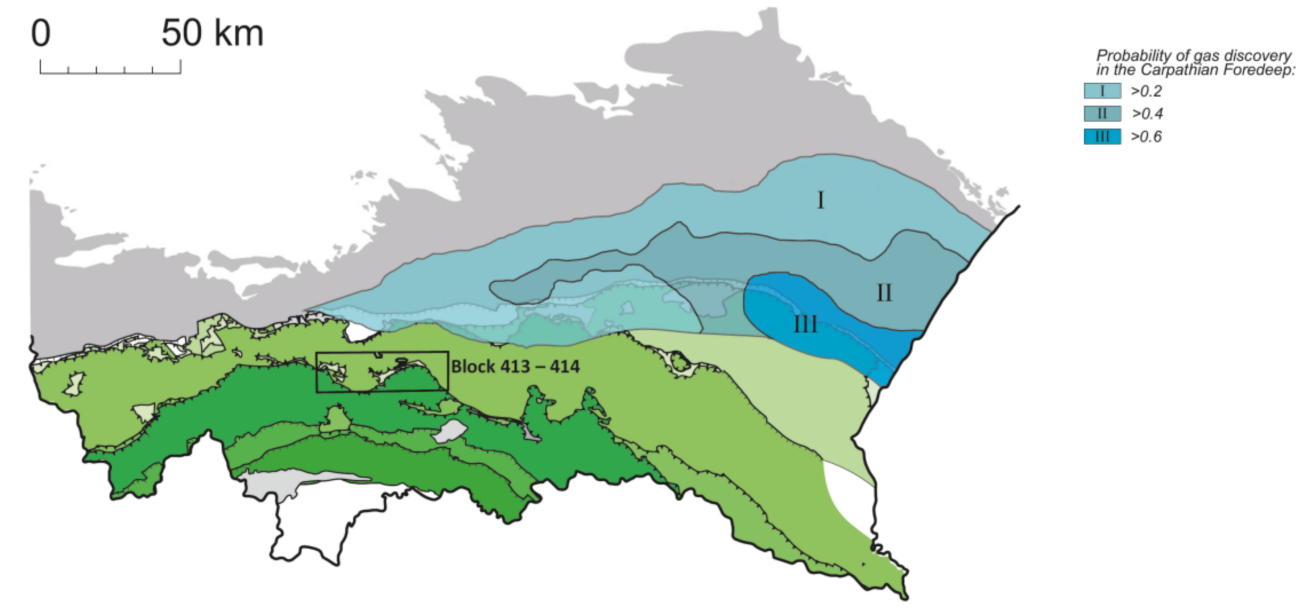

(c)

Figure 5. Hydrocarbon prospective areas in the Polish Outer Carpathians and Carpathian Foredeep: (a) zones of generation and expulsion of hydrocarbons from Paleozoic-Mesozoic basement of the Carpathian units [65] - possible petroleum exploration areas in the Southern Petroleum Province with the location of the Block 413-414 tender area; (b) zones prospective for conventional hydrocarbon occurrences in shallow and deep Carpathian structures ([66]; see also [27]) in the Southern Petroleum Province located in the Block 413-414 tender area; (c) zones with the highest discover the probability of gas-fields in the Miocene of the Carpathian Foredeep [67] in the Southern Petroleum Province located in the Block 413-414 tender area.

\section{Results}

\subsection{Block $413-414$}

The Block $413-414$ tender area of $666.20 \mathrm{~km}^{2}$ (164,621 ac) is located in southern Poland, in the Southern Petroleum Province (Figures 2 and 5). The main exploration target is related here to conventional accumulations of gas and oil in the Silesian Nappe of the Outer Carpathians flysch belt, autochthonous Miocene of the Carpathian Foredeep, and Paleozoic-Mesozoic basement of the Carpathian units. These horizons were recognized by 118 lines of 2D seismic surveys, one 3D survey, as well as by 37 deep wells (Figure 6a). So far, four hydrocarbon fields have been discovered and documented in the close vicinity of the Block 413-414 tender area. These are the Łąkta and Łapanów gas fields accumulated in Jurassic limestones, Raciborsko gas field in the autochthonous Miocene of the Carpathian Foredeep, and Stopnice oil and gas field in the Silesian Unit of the Outer Carpathians (Figure 6a). Previously, the Block 413-414 tender area was subjected to the hydrocarbon prospecting and exploration concessions no 33/99/p, 25/2001/p, and 43/2010/p, which resulted in the discovery of several prospective structures in the autochthonous Miocene of the Carpathian Foredeep and Paleozoic-Mesozoic basement. 

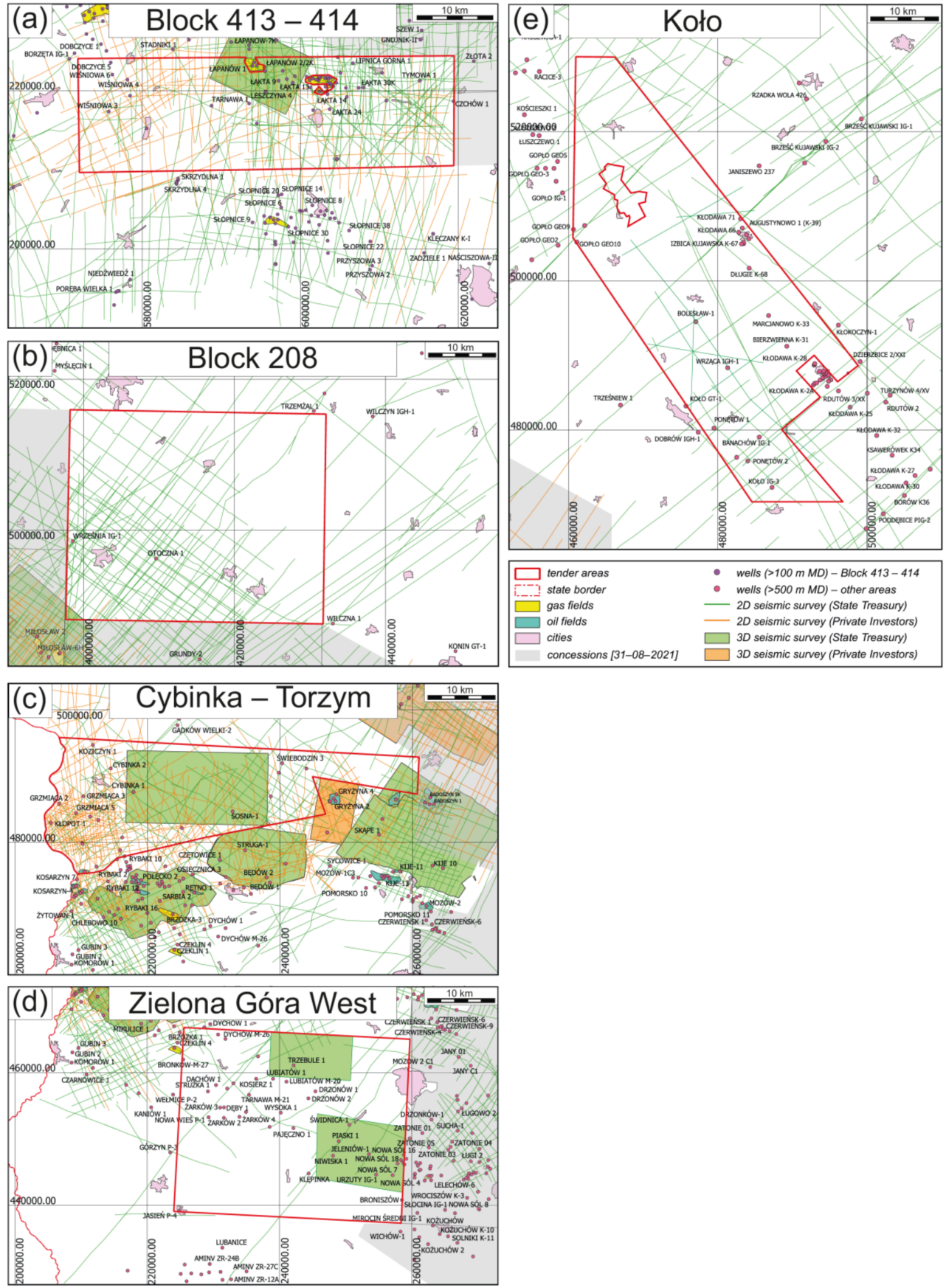

Figure 6. Location of the Block 413-414 (a), Block 208 (b), Cybinka-Torzym (c), Zielona Góra West (d), and Koło (e) tender areas in relation to the other prospecting and exploration concessions, seismic survey, deep wells, and oil and gas fields [68,69].

Block 413-414 is situated within the Outer Carpathians, at the border of the Magura, Fore-Magura, and Silesian Units (Figure 5). Below, the Sub-Silesian Unit and allochthonous Miocene of the Stebnik Units were identified in numerous wells. This folded and thrust succession covers the autochthonous Miocene of the Carpathian Foredeep. The deepest part is built of the Precambrian, Paleozoic and Mesozoic rocks of the Małopolska and Upper Silesian Blocks as the basement of the Carpathian units.

The following Magura, Fore-Magura, and Silesian units, composed of Cretaceous to Lower Miocene deposits attributed to different lithostratigraphic units of the Outer Carpathian flysch belt, occur as the uppermost structural elements in the Block 413-414 tender area. The Silesian Unit is the most important in terms of hydrocarbon exploration. It can be traced 
at the surface in the northern part of Block 413-414 and dips southwardly below the ForeMagura and Magura units to the depth above $2000 \mathrm{~m}$ b.g.l. (Figure 7). In the petroleum system developed in the Silesian Unit of the Outer Carpathians flysch belt, the Istebna and Krosno sandstones are assumed to be the principal reservoir rocks, in which gas and oil are accumulated in structural traps-fault-related synclines and anticlines, sealed by intercalations of fine-grained sediments, e.g., [70-73]. Hydrocarbons were generated from Menilite, Cieszyn, Verovice, and Lgota Beds (Figure 7), with TOC $=0.69-12.2 \%$, locally exceeding $20 \%$, and $\mathrm{HI}=49-713 \mathrm{mg} \mathrm{HC} / \mathrm{g}$ TOC in the former unit [74-84]. The process of generation of hydrocarbons has been continuous from the middle Miocene until the present in deep synclines and duplex zones in the Silesian Unit, e.g., [74].

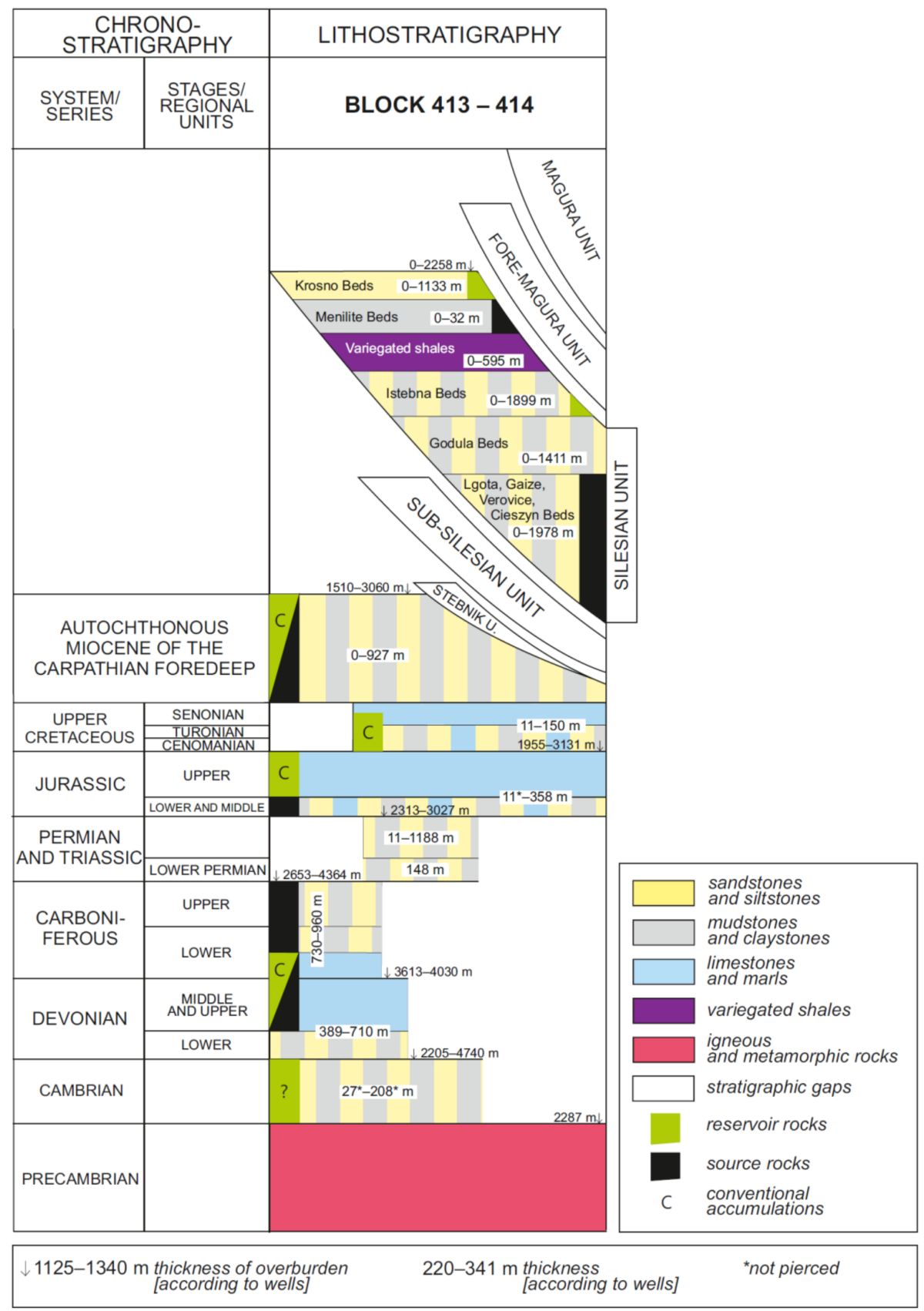

Figure 7. Stratigraphy, lithology, and petroleum system elements (horizons of source and reservoir rocks) in the Block 413-414 tender area dedicated to the 6th tender round for hydrocarbon concessions in Poland. 
The autochthonous Miocene of the Carpathian Foredeep occurs below the Outer Carpathians flysch, being buried to the depths 1510-3060 m b.g.l. and reaching up to $927 \mathrm{~m}$ in thickness (Figure 7). This succession comprises Badenian and Sarmatian sandstones intercalated with claystones and mudstones. In its upper part, the Miocene sediments are detached, folded, and overthrust as allochthonous Stebnik Unit over the autochthonous succession. The second petroleum system is developed in the Carpathian Foredeep. It comprises stratigraphic and structural traps related to the sandstones and sands, sealed locally by numerous intercalations of claystones and mudstones. The gas was generated from type III kerogen with a small admixture of type II from organic matter dispersed in fine-grained clastic rocks. TOC $=0.02-1.48 \%$ in the Upper Badenian and $0.02-3.22 \%$ in the Lower Sarmatian rocks with $\mathrm{HI}<200 \mathrm{mg} \mathrm{HC} / \mathrm{g}$ TOC and Tmax $=395^{\circ} \mathrm{C}$ and immature organic matter predominate; biogenic processes were the main factor responsible for gas generation [85-91]. Only in the deeply buried autochthonous Miocene deposits, below the Carpathian overthrust, may a low-temperature thermogenic generation occur [85-91]. The regional seal of the system is formed by the Stebnik and Carpathians napes.

The basement of the Block 413-414 is formed of Precambrian folded and slightly metamorphosed clasytones and conglomerates. Only one well-Wiśniowa 6-reached the Precambrian at a depth of $2287 \mathrm{~m}$ b.g.l. (Figure 7). Above, the Cambrian sandstones, mudstones and claystones occur, with thickness ranging from at least $27 \mathrm{~m}$ to $208 \mathrm{~m}$. They are covered by similar deposits attributed to the Lower Devonian, and above by the Middle to Upper Devonian carbonate rocks (organodetritic and organogenic limestones). The total thickness of the Devonian is up to $710 \mathrm{~m}$, and its upper surface lies at depth 3613-4030 m b.g.l. (Figure 7). The lowermost Carboniferous carbonates, as well as younger Carboniferous clastic rocks, form a 730-960 m thick complex, which upper surface was drilled at depth 2653-4364 m b.g.l. The Permian and probably Lower Triassic succession (up to $1337 \mathrm{~m}$ in thickness) is composed of different kinds of variegated clastics, recognized in the Liplas-Tarnawa tectonic trough (central part of the tender area). The listed above strata do not form a continuous cover in Block 413-414. Only the Jurassic succession occurs at the basement in the whole area, composed of carbonate-clastic rocks at the Lower to Middle Jurassic base and carbonate rocks at the top. The total thickness of the Jurassic succession is 11-358 m, and the depth of the top surface lies on 1955-3131 m b.g.1. (Figure 7). In the eastern part of the Block 413-414 tender area, the Jurassic is covered by Cenomanian and Turonian carbonate and clastic rocks and Senonian carbonates 11-150 m in thickness. The petroleum systems related to this Paleozoic-Mesozoic succession comprise hydrocarbons accumulated in Cambrian sandstones and the Devonian and Lower Carboniferous carbonates. In the Jurassic carbonates, as well as in the Cretaceous sandstones, commercial accumulations of gas and oil occur in the vicinity of the tender area. In the neighborhood of the Block 413-414 Kotarba et al. [65,92] indicated three horizons of source rocks: Middle to Upper Devonian carbonates with TOC $=0.0-2.6 \%$, Tmax $=428-466{ }^{\circ} \mathrm{C}$, $\mathrm{S} 2=0.0-7.4 \mathrm{mg} \mathrm{HC} / \mathrm{g}, \mathrm{HI}=0-367 \mathrm{mg} \mathrm{HC} / \mathrm{g}$ TOC, OI $=10-219 \mathrm{mg} \mathrm{CO} / \mathrm{g}$ TOC and predomination of type II kerogen, Carboniferous sediments: carbonates of Mississippian with TOC $=0.01-5.0 \%$, $\mathrm{Tmax}=416-468{ }^{\circ} \mathrm{C}, \mathrm{S} 2=0.13-13.7 \mathrm{mg} \mathrm{HC} / \mathrm{g}, \mathrm{HI}=37-361 \mathrm{mg} \mathrm{HC} / \mathrm{g}$ TOC, OI $=14-130 \mathrm{mg} \mathrm{CO}_{2} / \mathrm{g}^{\mathrm{TOC}}, \mathrm{R}_{\mathrm{O}}=0.92-1.0 \%$ and predomination of type II/III kerogen, and Mississippian clastics ("Kulm facies") with TOC $=0.00-2.8 \%$, Tmax $=432-451{ }^{\circ} \mathrm{C}$, $\mathrm{S} 2=0.33-3.0 \mathrm{mg} \mathrm{HC} / \mathrm{g}, \mathrm{HI}=47-116 \mathrm{mg} \mathrm{HC} / \mathrm{g}, \mathrm{OI}=7-73 \mathrm{mg} \mathrm{CO}_{2} / \mathrm{g}$ TOC and predomination of type II/III kerogen. Indicated also were Lower to Middle Jurassic shales with TOC $=0.0-15.7 \%$, Tmax $=407-432{ }^{\circ} \mathrm{C}, \mathrm{S} 2=0.22-43.1 \mathrm{mg} \mathrm{HC} / \mathrm{g}, \mathrm{HI}=62-467 \mathrm{mg} \mathrm{HC} / \mathrm{g}$ TOC, OI = 3-121 mg CO $2 / \mathrm{g}$ TOC and predomination of type III/II kerogen, but as immature they cannot be treated as source rock horizon. At least two stages of thermogenic hydrocarbon generation occurred in the Paleozoic-Mesozoic basement in the western part of the basement of the Carpathian Foredeep: first at the turn of the late Jurassic and early Cretaceous and second in the Miocene during the Carpathian overthrusting [65]. The petroleum expulsion process proceeded only from the Devonian and Carboniferous source rocks. The migration moved the expelled hydrocarbons to the Upper Jurassic carbon- 
ates and the Upper Cretaceous sandstones during overthrusts of the Carpathian nappes in the Miocene [65]. However, according to burial and thermal history modeling of the Paleozoic-Mesozoic basement in the central part of the Polish Outer Carpathians (between Cracow and Debica) [93], the Devonian and Carboniferous rocks cannot be an effective and important source rock for many Mesozoic petroleum fields, as their hydrocarbon potential was exhausted in the late Triassic to early Jurassic interval-before trap formation. The origin of hydrocarbons accumulated in the Mesozoic reservoirs is therefore in question: they may be generated from, e.g., Carpathian Oligocene Menilite shales and migrate to the Carpathian basement ([93], see also [94]).

\subsection{Block 208 Tender Area}

The Block 208 tender area of $946.10 \mathrm{~km}^{2}$ (233,786 ac) is located in the central-western part of Poland, in the Western Petroleum Province (Figures 2 and 4). The main exploration target here is related to unconventional accumulations of gas in the Permian Upper Rotliegend and Carboniferous horizons [27,38,95-97], secondary to conventional accumulations of oil and gas in the Zechstein Main Dolomite (Figures 2, 3 and 8). No hydrocarbon fields have been discovered within the Block 208 tender area (Figure 6b). However, in the south-west and south vicinity, 8 conventional gas fields have been discovered in the Upper Rotliegend sandstones: Kromolice S, Kromolice, Środa Wielkopolska, Winna Góra, Miłosław, Miłosław E, Lisewo, and Komorze. All these gas fields are documented, and some are developed, each of them being explored by 3D seismic surveys and at least a couple of wells. The Upper Rotliegend sandstones in these gas fields are of relatively low to medium permeability (0-19.88 mD); however, they can still be classified as conventional reservoir rocks. Tight gas accumulations have been discovered west of Block 208, on neighboring Siekierki-Trzek block 207, in several wells: Trzek 1, 2, and 3, and Krzesinki 1, in combined conventional structural and unconventional traps. These discoveries are still not being documented as gas fields. Tight gas accumulations have been discovered west on block 208, on neighboring Siekierki-Trzek block 207, in several wells (Trzek 1, 2, and 3 , and Krzesinki 1), in combined conventional structural traps and unconventional traps. These discoveries are still being not documented as gas fields. The Block 208 tender area was previously included in the hydrocarbon prospecting and exploration concession no $5 / 03 / p$, which resulted in the discovery of several prospective structures in the Rotliegend, which remained undrilled. Results of the studies in the frames of concession no. 5/03/p also pointed out a possibility of the existence of prospective reef structures within the Main Dolomite. However, such structures cannot be mapped using available 2D seismic data. No 3D seismic survey has been carried out there except a very small area in the SW corner of the Block 208 area, which covered neighboring hydrocarbon prospecting and exploration concessions. Available 2D seismic data include results of several 2D reflection seismic surveys completed in the 1970s, 1980s, and 1990s, generally covering SW part of the Block 208 area, 2D seismic surveys of 2005-2010 covering the southernmost part of the area (in total 10 profiles), a 2D seismic survey carried out in 2010 in the frames of the concession no 5/03/p (9 profiles) and the newest 2D seismic survey of 2019 covering most of the area (19 profiles; Figure 6b). NE part of the Block 208 area is unexplored by seismic. Only 2 deep wells-Otoczna 1 and Września IG-1—reached the Permian deposits within the tender area (Figure 6b).

The Block 208 area is situated in the Mogilno-Eódź segment of the Szczecin-Miechów Synclinorium, at the border of the Fore-Sudetic Monocline (Figure 4) [98,99]. Below, the Carboniferous strata of the Variscan Foreland basin occur, which covers the older Variscan basement (Figure 3). The thickness of the Main Dolomite recorded at depth $3769 \mathrm{~m} \mathrm{b.g.1.}$ in the only well drilling through Zechstein within the area is $3.5 \mathrm{~m}$. However, in another well, a few kilometers south, the Main Dolomite is $31 \mathrm{~m}$ thick and, according to results of 2D seismic, might have achieved similar thickness in southern and south-western parts of Block 208. The tender area is located quite far from any documented hydrocarbon field in the Main Dolomite-the closest one is the Buk oil and gas field located about $70 \mathrm{~km}$ 
westward (see [70]. This horizon can play the role of a closed petroleum system (sealed from base and top by Zechstein evaporites), in which source rocks are intercalated with carbonate reservoir rocks (Figure 8) [100].

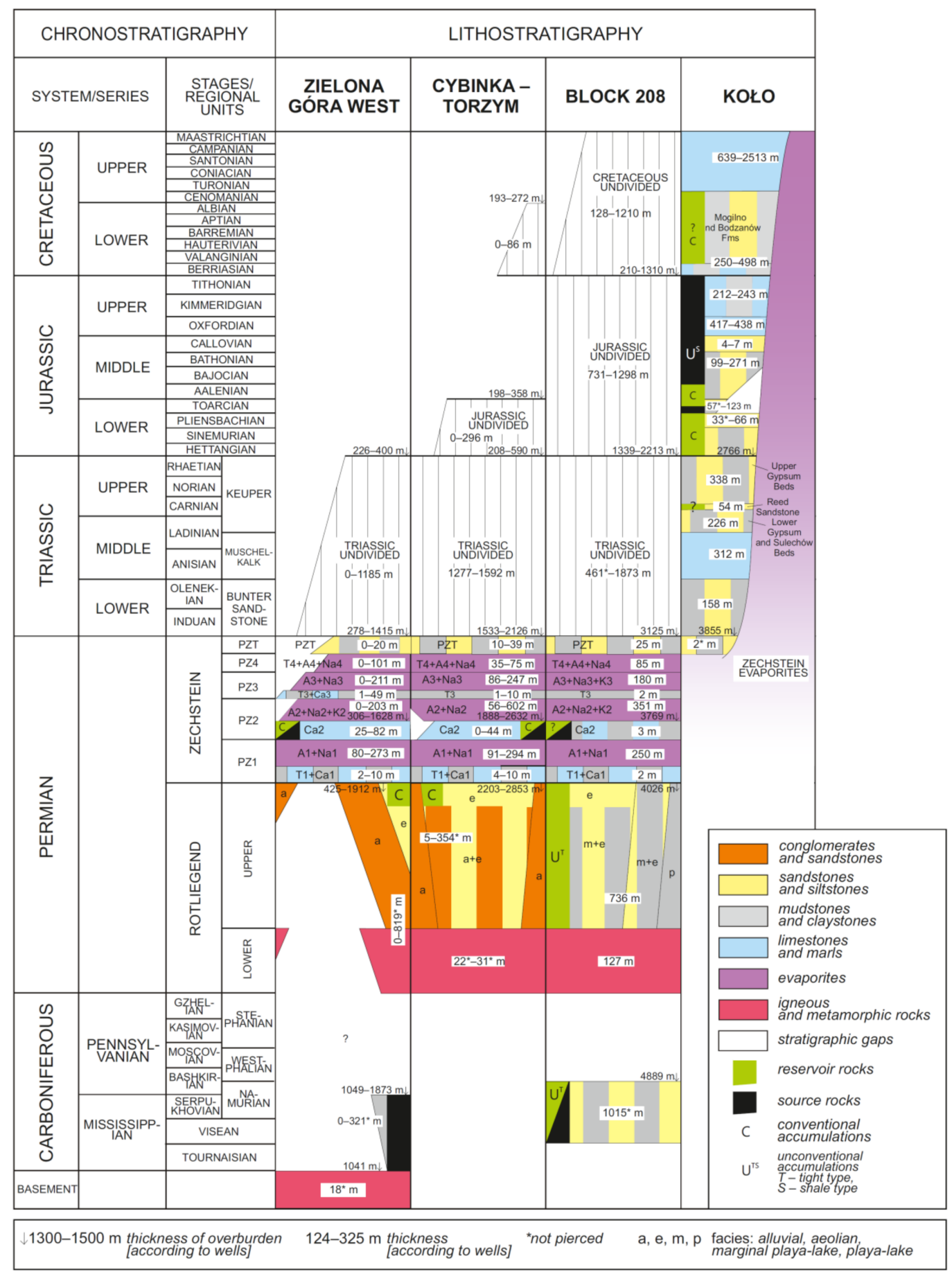

Figure 8. Stratigraphy, lithology, and petroleum system elements (horizons of source and reservoir rocks) in Block 208, Cybinka-Torzym, Zielona Góra West, and Koło tender area dedicated to the 6th tender round for hydrocarbon concessions in Poland.

The Upper Rotliegend horizon, which was drilled at depth $4026 \mathrm{~m}$ b.g.l. in the same well (Figure 8), generally includes $736 \mathrm{~m}$ fine-grained quartz sandstones with clayeycalcareous-ferruginous cement. Their petrophysical properties are varied [101,102]. The 
porosity of Rotliegend sandstones within the tender area and its immediate vicinity is estimated as of $9-16 \%$ at best and average permeability up to $1 \mathrm{mD}$, possibly within the range of tight reservoirs in some areas [101,102]. The sediments of the Upper Rotliegend are mainly eolian (in SW and S part) and marginal playa-lake facies (Figures 4 and 7). The gas was generated from deeply buried Carboniferous flysch sediments deposited in the Variscan Foreland basin [103].

The Lower Carboniferous horizon was drilled only at depth $4889 \mathrm{~m} \mathrm{b.g.l.} \mathrm{(Figure} \mathrm{8).} \mathrm{A}$ diverse lithology (sandstones, mudstones, and claystones) of $1015 \mathrm{~m}$ thick (not pierced) are characterized by relatively poor reservoir properties (mostly 1-2\% of total porosity, 0-3 mD of permeability) — permeability and porosity of sandstones might be unsuitable for either conventional or tight reservoirs [97]. Any prospects for tight reservoirs in Lower Carboniferous sediments in the Block 208 area should be considered in its southern and south-western parts.

\subsection{Cybinka-Torzym and Zielona Góra West Tender Areas}

The Cybinka-Torzym tender area of 668.50 km² (165.189 ac) and Zielona Góra West tender area of $954.57 \mathrm{~km}^{2}$ (235.879 ac) are located in western Poland in the Western Petroleum Province (Figures 2 and 4). The main exploration target is related here to conventional accumulations of gas and oil in the Permian Zechstein Main Dolomite and, less important, in the Upper Rotliegend horizons (Figures 2, 4 and 8) [96,102-112]. Numerous hydrocarbon fields have been discovered and documented in the southern and eastern part of the Cybinka-Torzym area in the Main Dolomite horizon (Brzózka, Czeklin, Gryżyna, Kije, Kije NE, Kosarzyn N, Koszarzyn S, Kosarzyn E, Ołobok; Figure 6c). These traps are visibly related to the palaeogeographic distribution of the carbonate platform edge zone facies, as well as their subsequent structural remodeling (Figure 4). So far, seismic surveys, including 219 profiles 2D and 3 surveys 3D, as well as 23 deep wells reaching or piercing the Main Dolomite, have been performed in the Cybinka-Torzym tender area (Figure 6c). Previously, the region was subjected to the hydrocarbon prospecting and exploration concessions no $6 / 2008 / \mathrm{p}$ and $8 / 2008 / \mathrm{p}$, which resulted in the discovery of several prospective structures in the Main Dolomite, which remained undrilled [7].

In the vicinity of the Zielona Góra West, the Mozów S, Czeklin, and Nowa Sól hydrocarbon fields have been discovered in the Main Dolomite (Figure 6d). So far, seismic surveys, including 35 lines 2D and 2 surveys 3D, as well as 37 deep wells reaching or piercing the Main Dolomite, have been in the Zielona Góra West tender area (Figure 6d). Previously, the region was subjected to the hydrocarbon prospecting and exploration concessions no 14/2007/p, which resulted in discovering the Niwisko structure in the Main Dolomite, assuming that oil and type of trap are analogous to the Nowa Sól field. Based on available data, the investor estimated the chance of geological success at $28 \%$ due to the possible absence of an effective seal.

The Cybinka-Torzym and Zielona Gora West areas are situated in the Fore-Sudetic Monocline-one of the main structural units of the Permian-Mesozoic (Laramide) succession (Figure 4) (see [98,99]). Below, the Carboniferous strata of the Variscan Foreland basin occur, which covers the older Variscan basement (Figure 3). The Main Dolomite is up to $44 \mathrm{~m}$ in thickness and buried up to 1888-2632 m b.g.l. in the Cybinka-Torzym tender area, and is up to $82 \mathrm{~m}$ in thickness and buried up to 306-1628 $\mathrm{m}$ b.g.l. in the Zielona Góra West tender area (Figure 8). In both cases, this horizon plays a role in the closed petroleum system, sealed from top and bottom by Zechstein evaporites (Figure 8), e.g., [104]. In this system, source rocks are intercalated with carbonate reservoir rocks. The Main Dolomite basin was highly variable in western Poland: platform lagoons were separated from the slope by carbonate sand bars, and the platform margin was dissected by large-scale deep embayments and intervening salients (Figure 4). Microbialites originated in the carbonate platform and slope environments, as well as basin fine-grained organic-rich sediments, are supposed to be the source rocks [105]. They were deposited close to reservoir facies within the same basin. Crude oils accumulated in the Main Dolomite rocks of the Fore-Sudetic Monocline were 
generated from type II kerogen. The natural gas usually contains considerable amounts of $\mathrm{H}_{2} \mathrm{~S}$. The main generation phase of liquid hydrocarbons from the Main Dolomite deposits span from the late Triassic, the early and the Middle Jurassic times up to the beginning of Late Jurassic [104].

The Rotliegend horizon, which is buried 2203-2853 m b.g.l. in the Cybinka-Torzym tender area and 425-1912 m b.g.l. in the Zielona Góra West tender area is an additional target for gas exploration in western Poland (Figures 4 and 8). The Rotliegend lithology includes finegrained quartz sandstones with clayey-calcareous-ferruginous cement. Their petrophysical properties are varied. The porosity of Rotliegend sandstones is $15-20 \%$ on average, and permeability varies from 2.5 to $60 \mathrm{mD}$, e.g., [70]. The sediments of the Upper Rotliegend are mainly eolian and less commonly fluvial facies (Figures 3 and 7) [55,95,113-117]. The gas accumulated within the Rotliegend is almost free of higher gaseous hydrocarbons and hydrogen sulfide but has admixtures of helium of up to $0.3-0.45 \%$. The gas quality decreases westwards, where 5-10\% (Cybinka-Torzym) and 10-20\% (Zielona Góra West) of methane, and $95-80 \%$ of nitrogen occur in hydrocarbon fields. The gas was generated from deeply buried Carboniferous flysch sediments deposited in the Variscan Foreland basin [103]. Carboniferous source rocks are mainly shales with dispersed organic matter $\mathrm{HI}$ values ranging from 60 to $360 \mathrm{mg} / \mathrm{g}$ TOC, $\mathrm{T}_{\max }=440-520{ }^{\circ} \mathrm{C}$ [118]. Organic-carbon content is generally low (up to $4 \%$ ). The organic material consists mainly of vitrinite group macerals, gas-prone type III kerogen [103]. Transformation ratios of Carboniferous deposits correlate to the thermogenic dry-gas phase, due to Early Permian magmatism, deep burial, and hydrothermal activity. The major trap formation and migration in Rotliegend probably took place during Triassic and Jurassic times [103]. The second migration phase in the Late Cretaceous was less intense during Laramide orogeny. The traps are mostly stratigraphic and may be stratigraphic/structural (fault-related) [119].

\subsection{Koło Tender Area}

The Koło tender area of $1035.32 \mathrm{~km}^{2}$ (255.883 ac) is located in central Poland, in the Western Petroleum Province (Figure 2). The main exploration target is related to possible conventional and unconventional accumulations of gas and oil expected in the Triassic, Jurassic, and Cretaceous rocks (Figure 8). Oil and gas fields within Mesozoic formations in the Koło tender area and its vicinity have not yet been discovered. Poor seismic (57 profiles 2D) and drilling (22 deep wells > $500 \mathrm{~m} \mathrm{MD)} \mathrm{investigations,} \mathrm{limited}$ mostly to the exploration of brown coal and salts deposits, have been performed in the Koło tender area (Figure 6e). Previously, the area was subjected to hydrocarbon prospecting and exploration concession no 53/2011/p, which resulted in the discovery of one prospective structure related to the Kłodawa salt diapir. This structure has not been drilled out.

The Koło area is situated at the borderland of the Mid-Polish Anticlinorium (Kujawy segment) and Szczecin-Łódź-Miechów Synclinorium (Mogilno-Lódź segment), which form the main structural units of the Permian-Mesozoic (Laramide) succession (Figure 4) [98,99]. This succession originated as one of the numerous Mesozoic epicontinental basins of the Central European Basin System [120,121]. The occurrence of NW-SE-oriented salt pillows and diapirs, with the Kłodawa, Ponętów-Wartkowice, and the Gopło diapirs as the largest ones, is typical for the area (Figures 4 and 8) [54]. These structures, formed of Zechstein evaporites, partly pierce the Mesozoic sediments, and the stratigraphic gaps may occur in the Mesozoic and Cenozoic deposits lying above and in the neighborhood. Since the oldest rocks drilled in the area are of the Upper Permian age, the pre-Permian basement is poorly recognized in the Koło tender area. It is presumed that Devonian and Carboniferous rocks of the Variscan Foredeep occur here (Figure 3) [98,99]. This is especially important since the Carboniferous rocks are considered the fundamental source rock not only for the Polish Lowlands but also for plenty of gas fields in Western Europe ([120-122], and citations therein). The most promising reservoirs are porous Lower and Middle Jurassic sandstones forming structural and combined structural-stratigraphic traps [123-125]. It is also possible that stratigraphic traps exist in the form of bioherms within the Oxfordian limestones, 
Lower Cretaceous sandstones, and channel fillings facies of fluvial Reed Sandstone (Upper Triassic), where gas shows have already been observed in wells from the Koło area and its vicinity. Potential traps are most likely closely related to intensive salt tectonics and may have various forms: from anticlinal structures above salt pillows, through structures induced by inversion, and above sub-Zechstein uplifts, to combined structural-stratigraphic traps next to the salt diapirs $[126,127]$. The hydrocarbon traps formation occurred during the Late Cretaceous inversion and deformations within the Permian-Mesozoic and older sediments, including rock faulting and plastic movements of Zechstein salts. Hypothetically, hydrocarbons were able to migrate from Carboniferous source rocks located in the Zechstein basement to the younger reservoirs of Permian and Mesozoic age sealed by the shales (Mesozoic) and evaporites (Permian, Triassic, Cretaceous). Moreover, some potential for unconventional hydrocarbon exploration in the Koło tender area is also postulated: TOC $=5.5-7.5 \%$ for Middle to Upper Jurassic rocks, which reached the initial main phase of the oil window in the Cretaceous time, was investigated; nevertheless, these rocks show no hydrocarbon expulsion ([128]; compare to [129]).

\section{Discussion}

So far, 56 areas prospective for new oil and gas discoveries were defined in Poland by PGS (see summary in PGS Report, 2021). A total of 32 of them became subjects of four tender rounds, which were organized by the Polish Ministry of Climate and Environment for granting the concessions for prospection and exploration of hydrocarbon deposits and exploitation of hydrocarbons from the deposit. As a result of performed tenders, 11 concessions have been granted. Another four areas: Gorzów Wielkopolski S, Gryfice, Kartuzy, and Sieldce $\mathrm{W}$ are subjected to the 5 th tender round for hydrocarbon concessions in Poland, planned in the first half of 2022 (Figures 2-4). These areas are dedicated to prospection and exploration of conventional oil and gas fields in the Middle Cambrian, Carboniferous, Permian-Rotliegend, and Permian-Zechstein/Main Dolomite, as well as unconventional gas accumulations in the Lower Paleozoic shales.

The areas described in this review are subjected to the 6th tender round for granting the concessions for prospection and exploration of hydrocarbon deposits and exploitation of hydrocarbons from the deposit, which is planned for 2022. Conventional accumulations of gas are highly expected in one Carpathian area-Block 413-414, in which Jurassic of the Carpathian basement, as well as Miocene of the Carpathian Foredeep and flysch succession of the Silesian Unit, are prospective. The Block 208 tender area brings possibilities of unconventional tight-gas exploration in the Permian-Rotliegend deposits and probably in the Carboniferous; moreover, some prospects are in question also in the Main Dolomite. In two cases, in the Cybinka-Torzym and Zielona Góra West areas, the main exploration target is related to conventional accumulations of gas and oil in the Permian-Zechstein/Main Dolomite, while the Upper Rotliegend is an additional horizon of exploration, bringing another opportunity for discoveries. In the Koło area, an exploration should focus on conventional gas accumulations in the Mesozoic succession in traps related to salt diapirs, and unconventional accumulations of shale gas are also possible in the Jurassic shales.

The detailed geological data of the tender areas (location, environmental restrictions, geology, petroleum plays, hydrocarbon deposits, wells, seismic surveys, gravimetry, magnetic and magnetotelluric surveys, as well as petroleum prospectives) are collected in the individual reports (so-called geological data packages), which will be published on the following websites when the tender begins: https://www.pgi.gov.pl/en/tender-blocks.html (accessed on 13 December 2021); https:/ /bip.mos.gov.pl/koncesje-geologiczne/przetargina-koncesje-na-poszukiwanie-rozpoznawanie-i-wydobywanie-weglowodorow / (accessed on 13 December 2021).

These data will also be available in the data room organized in the National Geological Archive (Polish Geological Institute-National Research Institute, 4 Rakowiecka Street, Warsaw, Poland) during the tender. 
An entity may also apply for a concession for any area that is not a subject of a tender or other concession (so-called open door procedure). However, the area cannot exceed $1200 \mathrm{~km}^{2}$. In both cases, the concession is granted for a period from 10 to 30 years and is divided into (I) the exploration phase and (II) the production phase (starts after obtaining an investment decision). If a deposit is documented or partly documented, it is also provided that the hydrocarbon production from the deposit can be started even as the exploration phase is still underway.

According to the recent proposals to change the geological and mining law in Poland, the extraction of hydrocarbons may be combined with the storage of carbon dioxide, which makes it possible to return to the many depleted oil and gas fields in Poland. This may be the industry's greatest growth impulse since the shale boom in Poland. Especially the Permian fields seem to be the best target because of their proven complete tightness. In the Cybinka-Torzym area, such a field is the Kosarzyn N oil field, in which $34.5 \mathrm{kTOE}$ (258 MBOE) of oil and 5.61 MCM (0.2 BCF) of gas from the recoverable resources were extracted until 2014 [69], while the initial geological resources were estimated at $109 \mathrm{kTOE}$ (816 MBOE) of oil. A recovery factor amounted to $31 \%$. The production was discontinued in 2014 due to the water cut of the Kosarzyn-8 well. Tests carried out on hydrocarbon deposits in the United States have proven that $\mathrm{CO}_{2}$ injection may increase the recovery factor from 5 to $25 \%$ [130], or, when selecting the most effective method, can be enhanced by $30-40 \%$ [131].

\section{Conclusions}

- The 6th international tender round for granting the concessions for prospection and exploration of hydrocarbon deposits and exploitation hydrocarbons from the deposit is planned for the second half of 2022.

- $\quad$ Five areas have been announced by the Polish Minister of Climate and Environment as the subject of the 6 th tender round. These are Block 413-414, located within the Outer Carpathians, Block 208, Cybinka-Torzym, Zielona Góra West, and Koło, located in the Polish Lowland.

- Conventional accumulations of hydrocarbons are expected in the Paleozoic-Mesozoic strata of the Carpathian basement, as well as in the autochthonous Miocene of the Carpathian Foredeep and the Outer Carpathians in the Block 413-414 area.

- Unconventional accumulations of tight-gas in the Lower Permian-Rotliegend and Carboniferous strata are expected in Block 208, while conventional accumulations of oil and gas in the Upper Permian-Zechstein/Main Dolomite rocks are less probable, although not completely excluded.

- The main exploration target of the Cybinka-Torzym and Zielona Góra West areas is related to the conventional accumulations of gas and oil in the Upper Permian-Zechstein/Main Dolomite and conventional accumulations of gas in the Lower Permian-Rotliegend.

- Conventional (salt-diapirs related traps) and unconventional (shale-type) gas accumulations are supposed to occur in the Mesozoic succession of the Koło area.

- The entities can also apply for a concession by submitting an application to the

- Ministry according to the open door policy.

- Concession is granted for 10 to 30 years and is divided into the prospecting and exploration phase and the production phase.

- The Polish Minister of Climate and Environment is the concession authority on the territory of Poland.

Author Contributions: Conceptualization and methodology, K.W. (Krystian Wójcik), J.Z. and M.Ł.; validation, T.P.; formal analysis, investigation and resources, S.W., H.K., K.W. (Krzysztof Waśkiewicz), A.W. and R.L.; writing—original draft preparation, K.W. (Krystian Wójcik), J.Z.; writing一review and editing, T.P.; supervision, K.S., A.C.-M. and J.S.; project administration, K.W. (Krystian Wójcik). All authors have read and agreed to the published version of the manuscript. 
Funding: This research and publication fee were financed by the National Fund for Environmental Protection and Water Management.

Institutional Review Board Statement: Not applicable.

Informed Consent Statement: Not applicable.

Data Availability Statement: Data supporting reported results can be found in the Polish National Geological Archives https: / / www.pgi.gov.pl/en/narodowe-archiwum-geologiczne-2.html (accessed on 13 December 2021) and on the tender area website https:/ / www.pgi.gov.pl/en/tender-blocks.html (accessed on 13 December 2021).

Acknowledgments: Helpful remarks, comments and suggestions, by Anonymous Reviewers, which greatly improve this text, are kindly acknowledged.

Conflicts of Interest: The authors declare no conflict of interest.

\section{References}

1. Czapigo-Czapla, M.; Brzeziński, D. Natural gas. In The Balance of Mineral Resources Deposits in Poland as Od 31-12-2020; Szuflicki, M., Malon, A., Tymiński, M., Eds.; Polish Geological Institute-National Research Institute: Warsaw, Poland, 2021 ; pp. 11-22. Available online: http://geoportal.pgi.gov.pl/css/surowce/images/2020/bilans_2020.pdf (accessed on 13 December 2021). (In Polish)

2. Czapigo-Czapla, M.; Brzeziński, D. Crude oil. In The Balance of Mineral Resources Deposits in Poland as Od 31-12-2020; Szuflicki, M., Malon, A., Tymiński, M., Eds.; Polish Geological Institute-National Research Institute: Warsaw, Poland, 2021 ; pp. $29-34$. Available online: http://geoportal.pgi.gov.pl/css/surowce/images/2020/bilans_2020.pdf (accessed on 13 December 2021). (In Polish)

3. Statistical Review of World Energy 2021; BP: London, UK, 2021; pp. 1-70. Available online: https://www.bp.com/content/dam/bp/ business-sites/en/global/corporate/pdfs/energy-economics/statistical-review/bp-stats-review-2021-full-report.pdf (accessed on 13 December 2021).

4. Wójcik, K.; Brzeziński, D.; Czapigo-Czapla, M.; Drążek, E.; Feldman-Olszewska, A.; Garecka, M.; Habryn, R.; Hadro, J.; Janas, M.; Jankowski, L.; et al. Petroleum Prospective of Poland, 2019; Polish Geological Institute-National Research Institute: Warsaw, Poland, 2019; pp. 1-52. Available online: https:/ /www.pgi.gov.pl/obszary-przetargowe/publikacje/8115-hydrocarbon-prospectivity-ofpoland-2019/file.html (accessed on 13 December 2021).

5. Karnkowski, P.H. Sedimentary basins and petroleum provinces in Poland: An overview. Przeglad Geol. 1997, 45, 989-995. Available online: https://geojournals.pgi.gov.pl/pg/article/view/16830 (accessed on 13 December 2021). (In Polish with English Summary)

6. Karnkowski, P.H. Petroleum provinces in Poland: A historical outline. Przeglad Geol. 2007, 55, 1061-1067. Available online: https:/ / geojournals.pgi.gov.pl/pg/article/view/31180 (accessed on 13 December 2021). (In Polish with English Summary)

7. Chmielowiec-Stawska, A.; Czekański, E. History and future of petroleum exploration on the Polish Lowland. Szejk 2013, 110, 8-18. Available online: https://pgnig.pl/documents/10184/2331814/Szejk_(110)_XII_2013.pdf/1609e3a2-0203-4d56-9690-6a6 6a225883a (accessed on 13 December 2021). (In Polish)

8. Li, G. World Atlas of Oil and Gas Basins, 1st ed.; Willey-Blackwell: Hoboken, NJ, USA, 2011; pp. 1-496.

9. Zelilidis, A.; Maravelis, A. Introduction to the Thematic Issue: Adriatic and Ionian Seas: Proven Petroleum Systems and Future Prospects. J. Pet. Geol. 2015, 38, 247-253. [CrossRef]

10. Wrigley, R.; Hodgson, N.; Esestime, P. Petroleum Geology and Hydrocarbon Potential of the Adriatic Basin, Offshore Croatia. J. Pet. Geol. 2015, 38, 301-316. [CrossRef]

11. Mascle, A.; Vially, R. The petroleum systems of the Southeast Basin and Gulf of Lion (France). Geol. Soc. London Spéc. Publ. 1999, 156, 121-140. [CrossRef]

12. Hu, H.Y.; Lu, S.; Xiao, H.Z. Petroleum Systems in the Paris Sedimentary Basin, Europe. Adv. Mater. Res. 2012, 616-618, 931-934. [CrossRef]

13. Del Olmo, W.M. The Spanish Petroleum Systems and the Overlooked Areas and Targets. Boletin Geológico Y Min. 2019, 130, 289-315. [CrossRef]

14. Cazzini, F.F. The history of the upstream oil and gas industry in Italy. Geol. Soc. Lond. Spéc. Publ. 2018, 465, 243-274. [CrossRef]

15. Lipparini, L.; D’ Ambrosio, A.; Trippetta, F.; Bigi, S.; Derks, J.F.; Bambridge, V.R.; Cassola, T. A new regional petroleum systems model for Central Italy and the central Adriatic Sea supported by basin modelling and an analysis of hydrocarbon occurrences. $J$. Pet. Geol. 2021, 44, 461-485. [CrossRef]

16. Gross, D.; Sachsenhofer, R.; Bechtel, A.; Gratzer, R.; Grundtner, M.; Linzer, H.; Misch, D.; Pytlak, L.; Scheucher, L. Petroleum systems in the Austrian sector of the North Alpine Foreland Basin: An overview. J. Pet. Geol. 2018, 41, 299-317. [CrossRef]

17. Golonka, J.; Picha, F.J. Introduction. In The Carpathians and Their Foreland: Geology and Hydrocarbon Resources; Golonka, J., Picha, F.J., Eds.; AAPG Memoir: Tulsa, OK, USA, 2006; Volume 89, pp. 1-9. [CrossRef] 
18. Ślączka, A.; Krugłov, S.; Golonka, J.; Oszczypko, N.; Popadyuk, I. Geology and Hydrocarbon Resources of the Outer Carpathians, Poland, Slovakia, and UkraineGeneral Geology. In The Carpathians and Their Foreland: Geology and Hydrocarbon Resources; Golonka, J., Picha, F.J., Eds.; AAPG Memoir: Tulsa, OK, USA, 2006; Volume 84, pp. 221-258. [CrossRef]

19. Pawlewicz, M. Total Petroleum Systems of the North Carpathian Province of Poland, Ukraine, Czech Republic, and Austria; U.S. Geological Survey Bulletin: Park, CL, USA, 2006; Volume 2204-E, pp. 1-26. [CrossRef]

20. Pawlewicz, M. Transylvanian Composite Total Petroleum System of the Transylvanian Basin Province, Romania, Eastern Europe; U.S. Geological Survey Bulletin: Park, CL, USA, 2005; Volume 2204-E, pp. 1-10. [CrossRef]

21. Pawlewicz, M. Total Petroleum Systems of the Carpathian-Balkanian Basin Province of Romania and Bulgaria; U.S. Geological Survey Bulletin: Park, CL, USA, 2007; Volume 2204-E, pp. 1-17. [CrossRef]

22. Stefaniuk, M.; Agh, A.G.-H.; Tytko, A. Oil Industry in the Carpathian Area-An Outline History, Current State and Development Prospects. Geomat. Landmanagement Landsc. 2014, 3, 65-80. [CrossRef]

23. Kotarba, M.J.; Więcław, D.; Bilkiewicz, E.; Radkovets, N.Y.; Koltun, Y.V.; Kmiecik, N.; Romanowski, T.; Kowalski, A. Origin and migration of oil and natural gas in the western part of the Ukrainian Outer Carpathians: Geochemical and geological approach. Mar. Pet. Geol. 2019, 103, 596-619. [CrossRef]

24. Krézsek, C. Petroleum Systems of Romania. AAPG Search and Discovery Article 2011; \#10349. Available online: https: //www.searchanddiscovery.com/pdfz/documents/2011/10349krezsek/ndx_krezsek.pdf.html (accessed on 13 December 2021).

25. Misch, D.; Sachsenhofer, R.; Groß, D.; Mahlstedt, N.; Bechtel, A. Conventional and Unconventional Petroleum System in the Dniepr-Donets Basin, Ukraine. In Efficient Use of Technology-Unlocking Potential, Proceedings of the 78th EAGE Conference and Exhibition, Vienna, Austria, 29-30 May 2016; European Association of Geoscientists \& Engineers: Houten, The Netherlands, 2016. [CrossRef]

26. Simmons, M.D.; Tari, G.C.; Okay, A.I. Petroleum geology of the Black Sea: Introduction. Geol. Soc. Lond. Spéc. Publ. 2018, 464, 1-18. [CrossRef]

27. Wójcicki, A.; Kiersnowski, H.; Podhalańska, T.; Janas, M.; Głuszyński, A.; Pacześna, J.; Adamczak-Biały, T. Shale gas, shale oil, tight gas. In Balance of the Prospective Mineral Resources in Poland as of 31.12.2018; Szamałek, K., Szuflicki, M., Mizerski, W., Eds.; Polish Geological Institute-National Research Institute: Warsaw, Poland, 2020; pp. 70-83. Available online: http: //geoportal.pgi.gov.pl/css/surowce/images/2020/bilans_perspektywicznych_zasobow_kopalin_Polski_2020.pdf (accessed on 13 December 2021). (In Polish)

28. Poprawa, P. Lower Paleozoic oil and gas shale in the Baltic-Podlasie-Lublin Basin (central and eastern Europe)—A review. Geol. Q. 2020, 64, 515-566. [CrossRef]

29. Karcz, P.; Janas, M.; Dyrka, I. Polish shale gas deposits in relation to selected shale gas perspective area of central and eastern Europe. Przeglad Geol. 2013, 61, 608-620, (In Polish with English Summary)

30. Topór, T.; Derkowski, A.; Ziemiański, P.P.; Marynowski, L.; McCarty, D.K. Multi-variable constraints of gas exploration potential in the Lower Silurian shale of the Baltic Basin (Poland). Int. J. Coal Geol. 2017, 179, 45-59. [CrossRef]

31. Kosakowski, P.; Kotarba, M.J.; Piestrzyński, A.; Shogenova, A.; Więcław, D. Petroleum source rock evaluation of the Alum and Dictyonema Shales (Upper Cambrian-Lower Ordovician) in the Baltic Basin and Podlasie Depression (eastern Poland). Geol. Rundsch. 2017, 106, 743-761. [CrossRef]

32. Golonka, J.; Bębenek, S. Construction of the Lower Paleozoic Extent's Maps Biostratigraphy and Analysis of Tectonic Evolution of the Marginal Zone of the Eastern European Platform for Estimation of Unconventional Hydrocarbon Deposits Distribution; Wydawnictwo Arka: Cieszyn, Poland, 2017; pp. 1-504. (In Polish)

33. Sowiżdżał, K.; Słoczyński, T.; Stadtmúller, M.; Kaczmarczyk, W. Lower Palaeozoic petroleum systems of the Baltic Basin in northern Poland: A 3D basin modeling study of selected areas (onshore and offshore). Interpretation 2018, 6, SH117-SH132. [CrossRef]

34. Papiernik, B.; Botor, D.; Golonka, J.; Porębski, S.J. Unconventional hydrocarbon prospects in Ordovician and Silurian mudrocks of the East European Craton (Poland): Insight from three-dimensional modelling of total organic carbon and thermal maturity. Ann. Soc. Geol. Pol. 2019, 89, 511-533. [CrossRef]

35. Matyasik, I.; Janiga, M.; Spunda, K. Evaluation of sweet spots in Polish shale formations in relation to the selected geochemical parameters. Nafta-Gaz 2020, 76, 76-90. [CrossRef]

36. Podhalańska, T.; Feldman-Olszewska, A.; Roszkowska-Remin, J.; Janas, M.; Pachytel, R.; Głuszyński, A.; Roman, M. Prospective zones of unconventional hydrocarbon reservoirs in the Cambrian, Ordovician and Silurian shale formations of the East European Craton marginal zone in Poland. Geol. Q. 2020, 64, 342-376. [CrossRef]

37. Poprawa, P.; Kiersnowski, H. Tight gas reservoirs in Poland. Biul. Państwowego Inst. Geol. 2010, 439, 173-180, (In Polish with English Summary)

38. Kiersnowski, H.; Buniak, A.; Kuberska, M.; Srokowska-Okońska, A. Tight gas accumulation in Rotliegend sandstones of Poland. Przeglad Geol. 2010, 58, 335-346. Available online: https://geojournals.pgi.gov.pl/pg/article/view/29885 (accessed on 13 December 2021). (In Polish with English Summary)

39. Adamczak-Biały, T.; Pacześna, J. Prospects of tight gas occurrence in the Middle Cambrian sandstones in the western part of the Baltic Depression (Łeba Ele-vation)_Introductory analysis based on petrophysical and well logging data. Przeglad Geol. 2020, 68, 701-709. [CrossRef] 
40. Kwarciński, J.; Hadro, J. Coalbed methane in the Upper Silesian Coal Basin. Przeglad Geol. 2008, 56, 485-490. Available online: https://geojournals.pgi.gov.pl/pg/article/view/30641 (accessed on 13 December 2021). (In Polish)

41. Hadro, J.; Wójcik, I. Coalbed methane: Resources and recovery. Przeglad Geol. 2013, 61, 404-410. Available online: https: / / geojournals.pgi.gov.pl/pg/article/view/28094 (accessed on 13 December 2021). (In Polish with English Summary)

42. Kędzior, S.; Kotarba, M.J.; Pękała, Z. Geology, spatial distribution of methane content and origin of coalbed gases in Upper Carboniferous (Upper Mississippian and Pennsylvanian) strata in the south-eastern part of the Upper Silesian Coal Basin, Poland. Int. J. Coal Geol. 2013, 105, 24-35. [CrossRef]

43. Kotarba, M.J.; Bilkiewicz, E.; Jurek, K.; Waliczek, M.; Więcław, D.; Zych, H. Thermogenic gases generated from coals and carbonaceous shales of the Upper Silesian and Lublin coal basins: A hydrous pyrolysis approach. Geol. Q. 2021, 65, 26. [CrossRef]

44. Waksmundzka, M.I.; Buła, Z. Geological Map of Poland without Permian, Mesozoic and Cenozoic Deposits. In Geological Atlas of Poland; Nawrocki, J., Becker, A., Eds.; Polish Geological Institute-National Research Institute: Warsaw, Poland, 2020.

45. Stolarczyk, F.; Stolarczyk, J.; Wysocka, H. Primary areas for hydrocarbon prospecting in the Cambrian of the Polish part of the East European Platform. Przeglad Geol. 2004, 52, 403-412. Available online: https://geojournals.pgi.gov.pl/pg/article/view/32029 (accessed on 13 December 2021). (In Polish with English Summary)

46. Kotarba, M.J. Geology, ecology and petroleum of the lower Paleozoic strata in the Polish part of the Baltic region. Geol. Q. 2010, 54,103-108. Available online: https:/ / gq.pgi.gov.pl/article/view/7560/6195 (accessed on 13 December 2021).

47. Narkiewicz, M.; Kotarba, M.; Kosakowski, P.; Wróbel, M.; Burzewski, W. Strefy perspektywiczne dla występowania ropy naftowej i gazu ziemnego w dewonie i karbonie basenu lubelskiego. In Ocena Stopnia Rozpoznania Polskich Basenów Naftowych; Górecki, W., Zawisza, L., Eds.; AGH University of Science and Technology: Cracow, Poland, 2011; Volume 6, pp. 186-188. (In Polish)

48. Feldman-Olszewska, A.; Kiersnowski, H.; Peryt, T.; Pacześna, J.; Laskowicz, R.; Janas, M.; Głuszyński, A.; Waśkiewicz, K. Crude oil, natural gas, condensate. In Balance of the Prospective Mineral Resources in Poland as of 31.12.2018; Szamałek, K., Szuflicki, M., Mizerski, W., Eds.; Polish Geological Institute-National Research Institute: Warsaw, Poland, 2020; pp. 49-69. Available online: http:/ /geoportal.pgi.gov.pl/css/surowce/images/2020/bilans_perspektywicznych_zasobow_kopalin_Polski_2020.pdf (accessed on 13 December 2021). (In Polish)

49. Helcel-Weil, M.; Dzięgielowski, J. Lublin Basin-Petroleum prospecting results and their importance for future exploration. Przeglad Geol. 2003, 51, 764-770. Available online: https://geojournals.pgi.gov.pl/pg/article/view/14058 (accessed on 13 December 2021). (In Polish with English Summary)

50. Helcel-Weil, M.; Dzięgielowski, J.; Florek, R.; Maksym, A.; Słyś, M. The Lublin basin: Petroleum exploration results and their importance for future prospects. Biul. Państwowego Inst. Geol. 2007, 422, 51-61. Available online: https://geojournals.pgi.gov.pl/ bp/article/view/32267 (accessed on 13 December 2021). (In Polish with English Summary)

51. Kotarba, M.J. Origin of hydrocarbon gases accumulated in the Middle Cambrian reservoirs of the Polish part of the Baltic region. Geol. Q. 2010, 54, 197-204. Available online: https://gq.pgi.gov.pl/article/view/7567/6202 (accessed on 13 December 2021).

52. Wiecław, D.; Kotarba, M.J.; Kowalski, A. Origin of oils accumulated in the Middle Cambrian reservoirs of the Polish part of the Baltic region. Geol. Q. 2010, 54, 205-216. Available online: https://gq.pgi.gov.pl/article/view/7568/6203 (accessed on 13 December 2021).

53. Semyrka, R.; Jarzyna, J.; Semyrka, G.; Kaźmierczuk, M.; Pikulski, L. Reservoir parameters of lithostratigraphic successions of the lower Paleozoic strata in the Polish part of the Baltc region based on laboratory studies and well logs. Geol. Q. 2010, 54, 227-240. Available online: https:/ /gq.pgi.gov.pl/article/view/7570/6205 (accessed on 13 December 2021).

54. Dadlez, R.; Marek, S.; Pokorski, J. Geological Map of Poland without Cenozoic Deposits, 1:1,000,000; Polish Geological Institute: Warsaw, Poland, 2000.

55. Kiersnowski, H.; Buniak, A.; Waśkiewicz, K. Lithofacies Map of the Upper Rotliegend in Poland; Polish Geological Institute-National Research Institute: Warsaw, Poland, 2020.

56. Wagner, R. Palaeogeographic Map of the Main Dolomite in Poland; Polish Geological Institute-National Research Institute: Warsaw, Poland, 2012.

57. Rozporządzenie Rady Ministrów z dnia 30 grudnia 2020 r. w sprawie wniosku o przeprowadzenie postępowania kwalifikacyjnego. J. Laws Repub. Pol. 2021, 73, 1-8. Available online: http://isap.sejm.gov.pl/isap.nsf/DocDetails.xsp?id=WDU20210000073 (accessed on 13 December 2021). (In Polish)

58. Polish Geological and Mining Law. Act of 9 June 2011. J. Laws Repub. Pol. 2011, 163, 1-243. Available online: http:/ / isap.sejm.gov. pl/isap.nsf/DocDetails.xsp?id=wdu20111630981 (accessed on 13 December 2021). (In Polish)

59. Jagielski, G.; Feldman-Olszewska, A.; Janas, M.; Kiersnowski, H.; Krzyżak, E.; Podhalańska, T.; Roszkowska-Remin, J.; Sobień, K.; Wójcik, K. Oil and gas in Poland-Prospects and licensing rounds in 2018 in terms of hydrocarbon concessions (part I). Przeglą Geol. 2018, 66, 724-740. Available online: https://geojournals.pgi.gov.pl/pg/article/view/27018 (accessed on 13 December 2021). (In Polish with English Summary)

60. Feldman-Olszewska, A.; Jankowski, L.; Krzyżak, E.; Peryt, T.; Sikorska-Jaworowska, M.; Wójcik, K. Oil and gas in PolandProspects and licensing rounds in 2018/2019 in terms of hydrocarbon concessions (part II). Przeglad Geol. 2019, 67, 13-26. Available online: https://geojournals.pgi.gov.pl/pg/article/view/26773 (accessed on 13 December 2021). (In Polish with English Summary) 
61. Jagielski, G.; Jankowski, L.; Kiersnowski, H.; Kijewska, S.; Kozłowska, A.; Krzyżak, E.; Kuberska, M.; Laskowicz, R.; Rosowiecka, O.; Roszkowska-Remin, J.; et al. Prospection, exploration and production of hydrocarbons in Poland in 2019 and 2020-tender procedure vs open door policy. Przeglad Geologiczny 2019,67, 938-960. Available online: https://geojournals.pgi.gov.pl/pg/ article/view/29650 (accessed on 13 December 2021). (In Polish with English Summary)

62. Jagielski, G.; Kiersnowski, H.; Kijewska, S.; Kozłowska, A.; Krzyżak, E.; Kuberska, M.; Laskowicz, R.; Roszkowska-Remin, J.; Smajdor, Ł.; Wesołowski, M.; et al. Oil and gas in Poland: Licensing round and the open door policy in 2019 and 2020. Zesz. Nauk. Inst. Gospod. Surowcami Miner. Energia Pol. Akad. Nauk 2019, 108, 127-140. Available online: https://znigsme.min-pan.krakow.pl/ Author-Tomasz-\%C5\%BBuk/141578 (accessed on 13 December 2021). (In Polish with English Summary)

63. Jagielski, G.; Kijewska, S.; Krzyżak, E.; Kumek, J.; Rosowiecka, O.; Roszkowska-Remin, J.; Słosmki, P.; Smajdor, Ł.; Wesołowski, M.; Wójcik, K. Prospection, exploration and production of hydrocarbons in Poland-licensing procedures and petroleum prospectives in 2021. Przegląd Geol. 2020, 68, 729-743. Available online: https://geojournals.pgi.gov.pl/pg/article/view/29775 (accessed on 13 December 2021). (In Polish with English Summary)

64. Public Information Bulletin of the Polish Ministry of Climate and Environment. Available online: https://bip.mos.gov.pl/ $\mathrm{pl} /$ koncesje-geologiczne/przetargi-na-koncesje-na-poszukiwanie-rozpoznawanie-i-wydobywanie-weglowodorow/szostarunda-przetargow-2022/ (accessed on 13 December 2021). (In Polish)

65. Kotarba, M.J.; Więcław, D.; Kosakowski, P.; Wróbel, M.; Matyszkiewicz, J.; Buła, Z.; Krajewski, M.; Koltun, Y.; Tarkowski, J. Petroleum systems in the Palaeozoic-Mesozoic basement of the Polish and Ukrainian parts of the Carpathian Foredeep. Ann. Soc. Geol. Pol. 2011, 81, 487-522. Available online: http://www.asgp.pl/81_3_487_522 (accessed on 13 December 2021).

66. Poprawa, P.; Malata, T.; Olszewska, B.; Szydło, A.; Garecka, M. Reconstruction of Petroleum Systems in the Polish Outer Carpathians; Inv. 107/2011; Polish Geological Institute-National Research Institute: Warsaw, Poland, 2010. (In Polish)

67. Górecki, W.; Zawisza, L. Recognition of the Polish Petroleum Baśni-State of View; AGH University of Science and Technology: Cracow, Poland, 2011; Volume I-X. (In Polish)

68. CGDB. Central Geological Database. 2011. Available online: http://geoportal.pgi.gov.pl (accessed on 13 December 2021).

69. MIDAS. System of Management and Protection of Mineral Resources in Poland. 2011. Available online: http://geoportal.pgi.gov. $\mathrm{pl} / \mathrm{portal} / \mathrm{page} / \mathrm{portal} / \mathrm{midas}$ (accessed on 13 December 2021).

70. Karnkowski, P. Oil and Gas Deposits in Poland; Geosynoptics Society: Cracow, Poland, 1999; pp. 1-380.

71. Dziadzio, P.S.; Borys, Z.; Kuk, S.; Maslowski, E.; Probulski, J.; Pietrusiak, M.; Górka, A.; Moryc, J.; Baszkiewicz, A.; Karnkowski, P.; et al. Hydrocarbon Resources of the Polish Outer Carpathians-Reservoir Parameters, Trap Types, and Selected Hydrocarbon Fields: A Stratigraphic Review. In The Carpathians and Their Foreland: Geology and Hydrocarbon Resources; Golonka, J., Picha, F.J., Eds.; AAPG Memoir: Tulsa, OK, USA, 2006; Volume 84, pp. 259-292.

72. Dziadzio, P.S.; Enfield, M.A.; Watkinson, M.P.; Porebski, S. The Ciężkowice Sandstone: Examples of Basin-floor Fan-stacking Patterns from the Main(Upper Paleocene to Eocene) Reservoir in the Polish Carpathians. In The Carpathians and Their Foreland: Geology and Hydrocarbon Resources; Golonka, J., Picha, F.J., Eds.; AAPG Memoir: Tulsa, OK, USA, 2006; Volume 84, pp. 477-496.

73. Dziadzio, P.S. The Geology of the Weglowka Oil Field, Subsilesian Unit, Polish Outer Carpathians. In The Carpathians and Their Foreland: Geology and Hydrocarbon Resources; Golonka, J., Picha, F.J., Eds.; AAPG Memoir: Tulsa, OK, USA, 2006; Volume 84, pp. 467-476. [CrossRef]

74. Matyasik, I.; Dziadzio, P.S. Reconstruction of petroleum systems based on integrated geochemical and geological investigations: Selected examples from the Middle Outer Carpathians in Poland. In The Carpathians and Their Foreland: Geology and Hydrocarbon Resources; Golonka, J., Picha, F.J., Eds.; AAPG Memoir: Tulsa, OK, USA, 2006; Volume 84, pp. 497-519. [CrossRef]

75. Kotarba, M.J.; Curtis, J.B.; Lewan, M.D. Comparison of natural gases accumulated in Oligocene strata with hydrous pyrolysis from Menilite Shales of the Polish Outer Carpathians. Org. Geochem. 2009, 40, 769-783. [CrossRef]

76. Kotarba, M.J.; Więcław, D.; Dziadzio, P.S.; Kowalski, A.; Bilkiewicz, E.; Kosakowski, P. Organic geochemical study of source rocks and natural gas and their genetic correlation in the central part of the Polish Outer Carpathians. Mar. Pet. Geol. 2013, 45, 106-120. [CrossRef]

77. Kotarba, M.J.; Więcław, D.; Dziadzio, P.S.; Kowalski, A.; Kosakowski, P.; Bilkiewicz, E. Organic geochemical study of source rocks and natural gas and their genetic correlation in the eastern part of the Polish Outer Carpathians and Palaeozoic-Mesozoic basement. Mar. Pet. Geol. 2014, 56, 97-122. [CrossRef]

78. Dziadzio, P.S.; Matyasik, I.; Garecka, M.; Szydło, A. Lower Oligocene Menilite Beds, Polish Outer Carpathians: Supposed deep-sea flysch locally reinterpreted as shelf, based on new sedimentological, micropalaeontological and organic-geochemical data. Pr. Nauk. Inst. Naft. Gazu Państwowego Inst. Badaw. 2016, 213, 213. [CrossRef]

79. Kotarba, M.J.; Więcław, D.; Bilkiewicz, E.; Lillis, P.G.; Dziadzio, P.S.; Kmiecik, N.; Romanowski, T.; Kowalski, A. Origin, migration and secondary processes of oil and natural gas in the central part of the Polish Outer Carpathians. Mar. Pet. Geol. 2020, 121, 104617. [CrossRef]

80. Więcław, D.; Bilkiewicz, E.; Kotarba, M.; Lillis, P.; Dziadzio, P.S.; Kowalski, A.; Kmiecik, N.; Romanowski, T.; Jurek, K. Origin and secondary processes in petroleum in the eastern part of the Polish Outer Carpathians. Int. J. Earth Sci. 2020, 109, 63-99. [CrossRef]

81. Zielińska, M.; Fabiańska, M.; Więcław, D.; Misz-Kennan, M. Comparative petrography and organic geochemistry of different types of organic matter occurring in the Outer Carpathians rocks. Geol. Q. 2020, 64, 165-184. [CrossRef]

82. Dziadzio, P.S.; Matyasik, I. Sedimentological and geochemical characterisation of the Lower Oligocene Menilite shales from the Magura, Dukla, and Silesian nappes, Polish Outer Carpathians-A new concept. Mar. Pet. Geol. 2021, 132, 105247. [CrossRef] 
83. Matyasik, I.; Labus, M.; Kierat, M.; Spunda, K. Differentiation of the generation potential of the Menilite and Istebna Beds of the Silesian Unit in the carpathians based on compiled pyrolytic studies. Energies 2021, 14, 6866. [CrossRef]

84. Kotarba, M.J.; Bilkiewicz, E.; Jurek, K.; Więcław, D.; Machowski, G. Origin, migration and secondary processes of oil and natural gas in the western part of the Polish Outer Carpathians: Geochemical and geological approach. Int. J. Earth Sci. 2021, 110, 1653-1679. [CrossRef]

85. Kotarba, M.J.; Peryt, T.; Koltun, Y.V. Microbial gas system and prospectives of hydrocarbon exploration in Miocene strata of the Polish and Ukrainian Carpathian Foredeep. Ann. Soc. Geol. Pol. 2011, 81, 523-548. Available online: http://www.asgp.pl/sites/ default/files/volumes/81_3_523_548.pdf (accessed on 13 December 2021).

86. Kotarba, M.J.; Peryt, T.M. Geology and petroleum geochemistry of Miocene strata in the Polish and Ukrainian Carpathian foredeep and its Palaeozoic-Mesozoic basement. Ann. Soc. Geol. Pol. 2011, 81, 211-220. Available online: https://geojournals.pgi. gov.pl/asgp/article/view/12531 (accessed on 13 December 2021).

87. Kotarba, M.J. Origin of natural gases in the autochthonous Miocene strata of the Polish Carpathian Foredeep. Ann. Soc. Geol. Pol. 2011, 81, 409-424. Available online: https:/ / geojournals.pgi.gov.pl/asgp/article/view/12543/11016 (accessed on 13 December 2021).

88. Kotarba, M.J.; Bilkiewicz, E.; Romanowski, T.; Waliczek, M.; Zych, H. Thermogenic hydrocarbon potential of Miocene strata of the Polish Carpathian Foredeep: Simulation by hydrous pyrolysis. In Proceedings of the 29th International Meeting on Organic Geochemistry, IMOG 2019, Gothenburg, Sweden, 1-6 September 2019. [CrossRef]

89. Kotarba, M.J.; Sumino, H.; Nagao, K. Origin of hydrocarbon and noble gases, carbon dioxide and molecular nitrogen in the Miocene strata of the eastern part of the Polish Carpathian Foredeep: Isotopic and geological approach. Appl. Geochem. 2020, 122, 104732. [CrossRef]

90. Sowiżdżał, K.; Słoczyński, T.; Sowiżdżał, A.; Papiernik, B.; Machowski, G. Miocene Biogas Generation System in the Carpathian Foredeep (SE Poland): A Basin Modeling Study to Assess the Potential of Unconventional Mudstone Reservoirs. Energies 2020, 13, 1838. [CrossRef]

91. Kotarba, M.J.; Więcław, D.; Jurek, K.; Waliczek, M. Variations of bitumen fraction, biomarker, stable carbon isotope and maceral compositions of dispersed organic matter in the Miocene strata (Carpathian Foredeep, Poland) during maturation simulated by hydrous pyrolysis. Mar. Pet. Geol. 2022, 137, 105487. [CrossRef]

92. Kotarba, M.; Więcław, D.; Bilkiewicz, E.; Dziadzio, P.; Kowalski, A. Genetic correlation of source rocks and natural gas in the Polish Outer Carpathians and Paleozoic-Mesozoic basement east of Kraków (southern Poland). Geol. Q. 2017, 61, 795-824. [CrossRef]

93. Botor, D. Burial and Thermal History Modeling of the Paleozoic-Mesozoic Basement in the Northern Margin of the Western Outer Carpathians (Case Study from Pilzno-40 Well, Southern Poland). Minerals 2021, 11, 733. [CrossRef]

94. Nemčok, M.; Henk, A. Oil reservoirs in foreland basins charged by thrustbelt source rocks: Insights from numerical stress modeling and geometric balancing in the West Carpathians. Geol. Soc. Lond. Spec. Publ. 2006, 253, 415-428. [CrossRef]

95. Buniak, A.; Kuberska, M.; Kiersnowski, H. Petrographical-petrophysical characteristics of the Rotliegend aeolian sandstones of the Siekierki-Winna Góra Zone (the Poznań Region) in the aspect of search for gas trapped in deposits. Przeglad Geol. 2009, 57, 328-334. Available online: https://geojournals.pgi.gov.pl/pg/article/view/30265 (accessed on 13 December 2021). (In Polish with English Summary)

96. Gast, R.E.; Dusar, M.; Breitkreuz, C.; Gaupp, R.; Schneider, J.W.; Stemmerik, L.; Geluk, M.C.; Geisler, M.; Kiersnowski, H.; Glennie, K.W.; et al. Rotliegend. In Petroleum Geological Atlas of the Southern Permian Basin Area; Doornenbal, J.C., Stevenson, A.G., Eds.; EAGE Publications b.v.: Houten, The Netherlands, 2010; pp. 101-121.

97. Kozłowska, A.; Kuberska, M. The Lower Carboniferous sandstones in the Wielkopolska-Silesia zone prospective for tight gas exploration (preliminary studies). Biul. Państwowego Inst. Geol. 2015, 464, 49-60. [CrossRef]

98. Żelaźniewicz, A.; Aleksandrowski, P.; Buła, Z.; Karnkowski, P.H.; Konon, A.; Ślacczka, A.; Żaba, J.; Żytko, K. Tectonic subdivision of Poland; Komitet Nauk Geologicznych PAN: Wrocław, Poland; pp. 1-64. Available online: http://www.kngpan.agh.edu.pl/wpcontent/uploads/Regionalizacja_Tektoniczna_Polski_20111.pdf (accessed on 13 December 2021). (In Polish)

99. Nawrocki, J.; Becker, A. Geological Atlas of Poland; Polish Geological Institute-National Research Institute: Warsaw, Poland, 2020; pp. 1-175.

100. Peryt, T.M.; Geluk, M.C.; Mathiesen, A.; Paul, J.; Smith, K. Zechstein. In Petroleum Geological Atlas of the Southern Permian Basin Area; Doornenbal, J.C., Stevenson, A.G., Eds.; EAGE Publications b.v.: Houten, The Netherlands, 2010; pp. $123-147$.

101. Darłak, B.; Kowalska-Włodarczyk, M.; Kobyłecka, A.; Leśniak, G.; Such, P. Przegląd wyników badań właściwości i filtracyjnych wybranych skał zbiornikowych basenów młodopaleozoicznych Niżu Polskiego. Pr. Państwowego Inst. Geol. 1998, 165, 147-154. (In Polish)

102. Maćkowski, T.; Kwolek, K.; Górecki, W. The potential for locating hydrocarbon traps in the Rotliegend formation, based on the results of experimental seismic surveys. Geol. Geophys. Environ. 2018, 43, 191. [CrossRef]

103. Botor, D.; Papiernik, B.; Maćkowski, T.; Reicher, B.; Kosakowski, P.; Machowski, G.; Górecki, W. Gas generation in Carboniferous source rocks of the Variscan foreland basin: Implications for a charge history of Rotliegend deposits with natural gases. Ann. Soc. Geol. Pol. 2013, 83, 353-383. Available online: https://geojournals.pgi.gov.pl/asgp/article/view/16458 (accessed on 13 December 2021). 
104. Kotarba, M.; Wagner, R. Generation potential of the Zechstein Main Dolomite $\left(\mathrm{Ca}_{2}\right)$ carbonates in the Gorzów WielkopolskiMidzychód-Lubiatów area: Geological and geochemical approach to microbial-algal source rock. Przegląd Geol. 2007, 55, 1025-1036. Available online: https://geojournals.pgi.gov.pl/pg/article/view/31177 (accessed on 13 December 2021).

105. Słowakiewicz, M.; Mikołajewski, Z. Upper Permian Main Dolomite microbial carbonates as potential source rocks for hydrocarbons (W Poland). Mar. Pet. Geol. 2011, 28, 1572-1591. [CrossRef]

106. Kosakowski, P.; Krajewski, M. Hydrocarbon potential of the Zechstein Main Dolomite in the western part of the Wielkopolska platform, SW Poland: New sedimentological and geochemical data. Mar. Pet. Geol. 2014, 49, 99-120. [CrossRef]

107. Kosakowski, P.; Krajewski, M. Hydrocarbon potential of the Zechstein Main Dolomite (Upper Permian) in western Poland: Relation to organic matter and facies characteristics. Mar. Pet. Geol. 2015, 68, 675-694. [CrossRef]

108. Kotarba, M.J.; Bilkiewicz, E.; Hałas, S. Mechanisms of generation of hydrogen sulphide, carbon dioxide and hydrocarbon gases from selected petroleum fields of the Zechstein Main Dolomite carbonates of the western part of Polish Southern Permian Basin: Isotopic and geological approach. J. Pet. Sci. Eng. 2017, 157, 380-391. [CrossRef]

109. Słowakiewicz, M.; Blumenberg, M.; Więcław, D.; Röhling, H.-G.; Scheeder, G.; Hindenberg, K.; Leśniak, A.; Idiz, E.F.; Tucker, M.E.; Pancost, R.D.; et al. Zechstein Main Dolomite oil characteristics in the Southern Permian Basin: I. Polish and German sectors panel. Mar. Pet. Geol. 2018, 93, 356-375, Corrigendum in Mar. Pet. Geol. 2018, 96, 647-648. [CrossRef]

110. Mikołajewski, Z.; Grelowski, C.; Kwolek, K.; Czechowski, F.; Słowakiewicz, M.; Matyasik, I.; Grotek, I. Hydrocarbon habitat in the Zielin Late Permian isolated carbonate platform, western Poland. Facies 2019, 65, 2. [CrossRef]

111. Kotarba, M.J.; Bilkiewicz, E.; Kosakowski, P. Origin of hydrocarbon and non-hydrocarbon $\left(\mathrm{H}_{2} \mathrm{~S}, \mathrm{CO}_{2}\right.$ and $\left.\mathrm{N}_{2}\right)$ components of natural gas accumulated in the Zechstein Main Dolomite carbonate reservoir of the western part of the Polish sector of the Southern Permian Basin. Chem. Geol. 2020, 554, 119807. [CrossRef]

112. Krogulec, E.; Sawicka, K.; Zabłocki, S.; Falkowska, E. Mineralogy and Permeability of Gas and Oil Dolomite Reservoirs of the Zechstein Main Dolomite Basin in the Lubiatów Deposit (Poland). Energies 2020, 13, 6436. [CrossRef]

113. Kiersnowski, H.; Buniak, A. Evolution of the Rotliegend Basin of northwestern Poland. Geol. Q. 2006, 50, 119-138. Available online: https:/ /gq.pgi.gov.pl/article/view/7401 (accessed on 13 December 2021).

114. Kiersnowski, H.; Peryt, T.M.; Buniak, A.; Mikołajewski, Z. From the intra-desert ridges to the marine carbonate island chain: Middle to late Permian (Upper Rotliegend-Lower Zechstein) of the Wolsztyn-Pogorzela high, west Poland. Geol. J. 2010, 45, 319-335. [CrossRef]

115. Kiersnowski, H. Late Permian aeolian sand seas from the Polish Upper Rotliegend basin in the context of palaeoclimatic periodicity. Geol. Soc. Spec. Publ. 2013, 376, 431-456. [CrossRef]

116. Kiersnowski, H.; Buniak, A. Sand sheets interaction with aeolian dune, alluvial and marginal playa beds in Late Permian Upper Rotliegend setting (western part of the Poznań basin, Poland). Geol. Q. 2016, 60, 771-800. Available online: https: / /gq.pgi.gov.pl/article/view/25584 (accessed on 13 December 2021). [CrossRef]

117. Krzywiec, P.; Kiersnowski, H.; Peryt, T. Fault-controlled Permian sedimentation in the central Polish Basin (Bydgoszcz-Szubin area)—insights from well and seismic data. Z. Dtsch. Ges. Geowiss. 2019, 170, 255-272. [CrossRef]

118. Breunese, J.N.; Andersen, J.H.; Brinkman, S.; Jagosiak, P.; Karnin, W.-D.; Karnkowski, P.H.; Kombrink, H.; Messner, J.; Mijnlieff, H.; Olsen, S.B.; et al. Reserves and production history. In Petroleum Geological Atlas of the Southern Permian Basin Area; Doornenbal, J.C., Stevenson, A.G., Eds.; EAGE Publications b.v.: Houten, The Netherlands, 2010; pp. 271-281.

119. Pletsch, T.; Appel, J.; Botor, D.; Clayton, C.J.; Duin, E.J.T.; Faber, E.; Górecki, W.; Kombrink, H.; Kosakowski, P.; Kuper, G.; et al. Petroleum generation and migration. In Petroleum Geological Atlas of the Southern Permian Basin Area; Doornenbal, J.C., Stevenson, A.G., Eds.; EAGE Publications b.v.: Houten, The Netherlands, 2010; pp. 224-253.

120. Ziegler, P.A. Geological Atlas of Western and Central Europe. Shell Internationale Petroleum Maatschappij, B.V.: Amsteradm, The Netherlands, 1990; pp. 1-239.

121. Scheck-Wenderoth, M.; Krzywiec, P.; Zülke, R.; Maystrenko, Y.; Frizheim, N. Permian to Cretaceous tectonics. In The Geology of Central Europe; McCann, T., Ed.; Geological Society of London: London, UK, 2008; pp. 999-1030.

122. Monaghan, A.A.; Underhill, J.R.; Marshall, J.E.A.; Hewett, A.J. Paleozoic plays of NW Europe: An introduction. Geol. Soc. Lond. Spec. Publ. 2018, 471, 1-15. [CrossRef]

123. Nowicki, M.; Wróbel, J.; Burzewski, W.; Radwański, S.; Myśko, A.; Siwek, T.; Hryniewiecka, A. Ilościowa ocena zasobów prognostycznych ropy naftowej i gazu ziemnego w kompleksach strukturalnych triasowo-jurajskim i kredowym Polski. Tech. Poszuk. Geol. 1990, 29, 47-50. (In Polish)

124. Labus, K.; Tarkowski, R.; Wdowin, M. Modeling gas-rock-water interactions in carbon dioxide storage capacity assessment: A case study of Jurassic sandstones in Poland. Int. J. Environ. Sci. Technol. 2014, 12, 2493-2502. [CrossRef]

125. Labus, K.; Tarkowski, R. Modeling hydrogen-Rock-Brine interactions for the Jurassic reservoir and cap rocks from Polish Lowlands. Int. J. Hydrogen Energy, 2022, in press. [CrossRef]

126. Krzywiec, P. Triassic evolution of the Kłodawa salt structure: Basement-controlled salt tectonics within the Mid-Polish Trough (Central Poland). Geol. Q. 2004, 48, 123-134. Available online: https://gq.pgi.gov.pl/article/view/7338 (accessed on 13 December 2021).

127. Krzywiec, P.; Peryt, T.M.; Kiersnowski, H.; Pomianowski, P.; Czapowski, G.; Kwolek, K. Permo-Triassic Evaporites of the Polish Basin and Their Bearing on the Tectonic Evolution and Hydrocarbon System, an Overview. In Permo-Triassic Salt Provinces of Europe, North Africa and the Atlantic Margins Tectonics and Hydrocarbon Potential; Soto, J.I., Flinch, J.F., Tari, G., Eds.; Elsevier: Amsterdam, The Netherlands; Oxford, UK; Cambridge, MA, USA, 2017; pp. 243-261. 
128. Kosakowski, P.; Wójcik-Tabol, P.; Kowalski, A.; Zacharski, J. Jurassic Petroleum System in the Polish Lowlands (Central Poland)— Organic Geochemical and Numerical Modelling Approach. In Proceedings of the 77th EAGE Conference \& Exhibition, IFEMA, Madrid, Spain, 1-4 June 2015. [CrossRef]

129. Więcław, D. Habitat and hydrocarbon potential of the Kimmeridgian strata in the central part of the Polish Lowlands. Geol. Q. 2016, 60, 192-210. [CrossRef]

130. Ghedan, S.G. Global Laboratory Experience of $\mathrm{CO}_{2}$-EOR Flooding. In Proceedings of the SPE/EAGE Reservoir Characterization and Simulation Conference, Abu Dhabi, United Arab Emirates, 19-21 September 2009. [CrossRef]

131. Lubaś, J.; Szott, W.; Dziadkiewicz, M. Analiza możliwości zwiększenia stopnia sczerpania zasobów złóż ropy naftowej w Polsce. Nafta Gaz 2012, 8, 481-489. Available online: http:/ / archiwum.inig.pl/INST/nafta-gaz/nafta-gaz/Nafta-Gaz-2012-08-01.pdf (accessed on 13 December 2021). (In Polish) 